\title{
Systematic Review of Caudal Epidural Injections in the Management of Chronic Low Back Pain
}

Ann Conn, MD1, Ricardo M. Buenaventura, MD², Sukdeb Datta, MD², Salahadin Abdi, MD, $\mathrm{PhD}^{4}$, and Sudhir Diwan, $\mathrm{MD}^{5}$

From: ${ }^{1}$ Premier Pain Center, Covington, LA; ${ }^{2}$ Pain Relief of Dayton, Centerville, $\mathrm{OH}$; ${ }^{3}$ Vanderbilt University Medical Center, Nashville, TN; 4University of Miami, Miller School of Medicine, Miami, FL; and ${ }^{5}$ New York Presbyterian Hospital, Weill Cornell Medical College New York, NY.

Dr. Conn is staff physician, Premier Pain Relief, Covington, LA Dr. Buenaventura is Medical Director, Pain Relief of Dayton, and Clinical Associate Professor,

Department of Surgery, Wright State University School o Medicine, Dayton, $\mathrm{OH}$

Dr. Datta is Director, Vanderbilt University Interventional Pain Program, Associate Professor, Dept. of Anesthesiology, Vanderbilt University Medical Center, Nashville, TN.

Dr. Abdi is Professor and Chief, Division of Pain Medicine,

Department of Anesthesiology,

Perioperative Medicine and Pain

Management, University of Miami, Miller School of Medicine, Miami, FL.

Dr. Diwan is Director of Pain

Medicine in the Department

of Anesthesiology, New York Presbyterian Hospital, the Director of the Tri-Institutional Pain Fellowship Program, Weill Cornel

Medical College, New York, NY

Address correspondence: Ann Conn, MD 7015 Highway 190 E. Service Road, \#101 Covington, LA 70433

E-mail: annconn@gmail.com

Disclaimer: There was no externa funding in the preparation of this manuscript. Conflict of interest: None.

Manuscript received: 10/7/2008 Accepted for publication: $10 / 30 / 2008$

Free full manuscript: www.painphysicianjournal.com
Background: Caudal epidural injection of local anesthetics with or without steroids is one of the most commonly used interventions in managing chronic low back and lower extremity pain. However, there has been a lack of well-designed randomized, controlled studies to determine the effectiveness of caudal epidural injections in various conditions - disc herniation and radiculitis, post-lumbar laminectomy syndrome, spinal stenosis, and chronic low back pain of disc origin without disc herniation or radiculitis.

Study Design: A systematic review of caudal epidural injections with or without steroids in managing chronic pain secondary to lumbar disc herniation or radiculitis, post lumbar laminectomy syndrome, spinal stenosis, and discogenic pain without disc herniation or radiculitis.

Objective: To evaluate the effect of caudal epidural injections with or without steroids in managing various types of chronic low back and lower extremity pain emanating as a result of disc herniation or radiculitis, post-lumbar laminectomy syndrome, spinal stenosis, and chronic discogenic pain.

Methods: A review of the literature was performed according to the Cochrane Musculoskeletal Review Group Criteria as utilized for interventional techniques for randomized trials and the Agency for Healthcare Research and Quality (AHRQ) criteria for observational studies.

The level of evidence was classified as Level I, II, or III based on the quality of evidence developed by the U.S. Preventive Services Task Force (USPSTF).

Data sources included relevant literature of the English language identified through searches of PubMed and EMBASE from 1966 to November 2008, and manual searches of bibliographies of known primary and review articles.

Outcome Measures: The primary outcome measure was pain relief (short-term relief $=$ up to 6 months and long-term $\geq 6$ months). Secondary outcome measures of improvement in functional status, psychological status, return to work, and reduction in opioid intake were utilized.

Results: The evidence showed Level I for short- and long-term relief in managing chronic low back and lower extremity pain secondary to lumbar disc herniation and/or radiculitis and discogenic pain without disc herniation or radiculitis. The indicated evidence is Level II-1 or II-2 for caudal epidural injections in managing low back pain of post-lumbar laminectomy syndrome and spinal stenosis.

Limitations: The limitations of this study include the paucity of literature, specifically for chronic pain without disc herniation.

Conclusion: This systematic review shows Level I evidence for relief of chronic pain secondary to disc herniation or radiculitis and discogenic pain without disc herniation or radiculitis. Further, the indicated evidence is Level II-1 or II-2 for caudal epidural injections in managing chronic pain of post lumbar laminectomy syndrome and spinal stenosis.

Key words: Chronic low back pain, lower extremity pain, lumbar disc herniation, lumbar radiculitis, lumbar discogenic pain, post lumbar laminectomy or surgery syndrome, spinal stenosis, caudal epidural injections, steroids, local anesthetic

Pain Physician 2009; 12:1:109-135 
A mong chronic pain disorders, low back pain arising from various structures of the spine constitutes the majority of problems (1). The lifetime prevalence of chronic low back pain has been reported as high as $80 \%$ with an annual prevalence ranging from $15 \%$ to $45 \%$, with a point prevalence of $30 \%(1-7)$. Studies of the prevalence of low back pain (6) and its impact on general health showed $25 \%$ of patients reporting Grade II to IV low back pain with high pain intensity with disability. Historically, even though back pain research has primarily focused on younger, working adults, and disc herniation, now there is clear evidence that back pain is one of the most frequent complaints in older persons $(2,8,9)$, and is an independent correlate of functional limitations $(8,10)$. Further, low back pain is associated with a significant economic, societal, and health impact $(11,12)$.

Kuslich et al (13) identified intervertebral discs, facet joints, ligaments, fascia, muscles, and nerve root dura as tissues capable of transmitting pain in the low back. The human intervertebral disc in the lumbar spine has been known to cause low back and lower extremity pain secondary to disc disruption, disc herniation, and nerve root compression (14-31). Nerve root compression may be caused by disc herniation, spinal stenosis, and osteoarthritis. Chemical radiculitis and residual pain after surgical interventions, also known as post surgery syndrome, are also common factors in the causation of low back and lower extremity pain related to the disc (27-31).

Epidural injections for managing chronic low back pain are one of the most commonly performed interventions in the United States (1,32-41). Friedly et al (39) reported multiple diagnostic codes used for epidural steroid injections as sciatica, radiculopathy, or herniated discs, and axial low back pain and spinal stenosis. The authors concluded that there is a lack of consensus regarding the indications for epidural steroid injections and is cause for concern given the large expenditures for these procedures.

Epidural injections in the lumbar spine are provided by caudal, lumbar interlaminar, or transforaminal routes. While interlaminar entry is considered to deliver the medication closely to the assumed site of pathology, the transforaminal approach is considered as target-specific requiring the smallest volume to reach the primary site of pathology. Caudal epidurals are considered as the safest and easiest, with minimal risk of inadvertent dural puncture, even though re- quiring relatively high volumes. They have also been shown to be significantly effective compared to interlaminar epidural injections $(1,41)$. Even then, controversy continues with regards to the medical necessity and indications of lumbar epidural injections. Multiple systematic reviews, guidelines, health technology assessments, and local medical review policies and coverage decisions, have been published (36-43). The evidence is highly variable from indeterminate to strong in various publications. Further, the benefit and most effective route of administration for epidural steroids remains controversial.

The underlying mechanism of action of epidurally administered steroid and local anesthetic injections is still not well understood. It is believed that the achieved neural blockade alters or interrupts nociceptive input, reflex mechanism of the afferent fibers, self-sustaining activity of the neurons, and the pattern of central neuronal activities $(1,44,45)$. Further, corticosteroids have been shown to reduce inflammation by inhibiting either the synthesis or release of a number of pro-inflammatory mediators and by causing a reversible local anesthetic effect (44-54). In contrast, local anesthetics have been described to provide short- to long-term symptomatic relief by suppression of nociceptive discharge (55-57), the block of axonal transport $(58,59)$ of the sympathetic reflex arch $(56)$, the block of sensitization (60), and anti-inflammatory effect (61). The long-lasting effect of local anesthetics in nerve blocks has been demonstrated in multiple studies (62-71). Sato et al (67) evaluated the prolonged analgesic effect of epidural bupivacaine in a rat model of neuropathic pain and concluded that repetitive administration of bupivacaine into the epidural space in rats exerts an analgesic effect, possibly by inducing a plastic change in nociceptive input. Further, Tachihara et al (72) showed in rats that nerve root infiltration prevented mechanical allodynia, however, no additional benefit from using corticosteroid was identified, suggesting that corticosteroid may be unnecessary for nerve root blocks.

Due to the multitude of conflicting opinions and controversy, this systematic review was undertaken to evaluate the clinical effectiveness of caudal epidural steroid injections and related complications in multiple conditions treated with caudal epidural injections including low back and/or lower extremity pain secondary to disc herniation, discogenic pain, spinal stenosis, and post lumbar surgery syndrome. 


\section{Methods}

\section{Literature Search}

A comprehensive literature search was conducted which included the search of databases including PubMed and EMBASE from 1966 through November 2008, Cochrane database, Clinical Trial Registry, systematic reviews, narrative reviews, and cross-references to the reviews published in the English language.

The search strategy emphasized chronic low back pain of discogenic origin with a focus on caudal epidural injections. Search terminology included lumbar intervertebral disc, disc-related pain, spinal stenosis, post surgery syndrome, and caudal epidural injections.

\section{Selection Criteria}

The review focused on randomized and observational studies, and reports of complications. The population of interest was patients suffering with chronic low back pain for at least 3 months. Only caudal epidural injections with or without steroids were evaluated. All the studies providing appropriate management with outcome evaluations of 6 months or longer and statistical evaluations were reviewed.

\section{Outcome Parameters}

The outcome measures were of documented pain relief at various points in time, functional assessment, and other outcomes including psychological improvement, return to work, and change in opioid intake.

\section{Methodologic Quality Assessment}

The quality of each individual article used in this analysis was assessed by modified Cochrane review criteria with weighted scores (Table 1) (43) for randomized trials and Agency for Healthcare Quality

Table 1. Modified and weighted Cochrane methodologic quality assessment criteria.

\begin{tabular}{|c|c|c|}
\hline \multicolumn{2}{|r|}{ CRITERION } & $\begin{array}{c}\text { Weighted } \\
\text { Score (points) }\end{array}$ \\
\hline \multicolumn{2}{|c|}{ 1. Study population } & 35 \\
\hline A & Homogeneity & 2 \\
\hline B & Comparability of relevant baseline characteristics & 5 \\
\hline $\mathrm{C}$ & Randomization procedure adequate & 4 \\
\hline $\mathrm{D}$ & Drop-outs described for each study group separately & 3 \\
\hline \multirow[t]{2}{*}{$\mathrm{E}$} & $<20 \%$ loss for follow-up & 2 \\
\hline & $<10 \%$ loss for follow-up & 2 \\
\hline \multirow[t]{2}{*}{$\mathrm{F}$} & $>50$ subject in the smallest group & 8 \\
\hline & $>100$ subjects in the smallest group & 9 \\
\hline \multicolumn{2}{|c|}{ 2. Interventions } & 25 \\
\hline G & Interventions included in protocol and described & 10 \\
\hline $\mathrm{H}$ & Pragmatic study & 5 \\
\hline $\mathrm{I}$ & Co-interventions avoided or similar & 5 \\
\hline $\mathrm{J}$ & Placebo-controlled & 5 \\
\hline \multicolumn{2}{|c|}{ 3. Effect } & 30 \\
\hline $\mathrm{K}$ & Patients blinded & 5 \\
\hline $\mathrm{L}$ & Outcome measures relevant & 10 \\
\hline M & Blinded outcome assessments & 10 \\
\hline $\mathrm{N}$ & Follow-up period adequate & 5 \\
\hline \multicolumn{2}{|c|}{ 4. Data-presentation and analysis } & 10 \\
\hline $\mathrm{O}$ & Intention-to-treat analysis & 5 \\
\hline $\mathrm{P}$ & Frequencies of most important outcomes presented for each treatment group & 5 \\
\hline & TOTAL SCORE & 100 \\
\hline
\end{tabular}

Adapted from Koes BW et al. Efficacy of epidural steroid injections for low-back pain and sciatica: A systematic review of randomized clinical trials. Pain 1995; 63:279-288 (43). 
and Criteria (AHRQ) quality criteria for assessment of observational studies (Table 2) (73) with consensusbased weighted scoring developed by the guidelines committee of the American Society of Interventional Pain Physicians (ASIPP) utilized in multiple evaluations $(37,74-78)$.

Table 2. Modified AHRQ quality assessment criteria for observational studies.

\begin{tabular}{|c|c|}
\hline CRITERION & Weighted Score (points) \\
\hline 1. Study Question & 2 \\
\hline \multicolumn{2}{|l|}{ - Clearly focused and appropriate question } \\
\hline 2. Study Population & 8 \\
\hline - Description of study population & 5 \\
\hline - Sample size justification & 3 \\
\hline 3. Comparability of Subjects for All Observational Studies & 22 \\
\hline - Specific inclusion/exclusion criteria for all groups & 5 \\
\hline - Criteria applied equally to all groups & 3 \\
\hline - Comparability of groups at baseline with regard to disease status and prognostic factors & 3 \\
\hline - Study groups comparable to non-participants with regard to confounding factors & 3 \\
\hline - Use of concurrent controls & 5 \\
\hline - Comparability of follow-up among groups at each assessment & 3 \\
\hline 4. Exposure or Intervention & 11 \\
\hline - Clear definition of exposure & 5 \\
\hline - Measurement method standard, valid and reliable & 3 \\
\hline - Exposure measured equally in all study groups & 3 \\
\hline 5. Outcome measures & 20 \\
\hline - Primary/secondary outcomes clearly defined & 5 \\
\hline - Outcomes assessed blind to exposure or intervention & 5 \\
\hline - Method of outcome assessment standard, valid and reliable & 5 \\
\hline - Length of follow-up adequate for question & 5 \\
\hline 6. Statistical Analysis & 19 \\
\hline - Statistical tests appropriate & 5 \\
\hline - Multiple comparisons taken into consideration & 3 \\
\hline - Modeling and multivariate techniques appropriate & 2 \\
\hline - Power calculation provided & 2 \\
\hline - Assessment of confounding & 5 \\
\hline - Dose-response assessment if appropriate & 2 \\
\hline 7. Results & 8 \\
\hline - Measure of effect for outcomes and appropriate measure of precision & 5 \\
\hline - Adequacy of follow-up for each study group & 3 \\
\hline 8. Discussion & 5 \\
\hline \multicolumn{2}{|l|}{ - Conclusions supported by results with possible biases and limitations taken into consideration } \\
\hline 9. Funding or Sponsorship & 5 \\
\hline \multicolumn{2}{|l|}{ - Type and sources of support for study } \\
\hline TOTAL SCORE & 100 \\
\hline
\end{tabular}

Adapted and modified from West S et al. Systems to Rate the Strength of Scientific Evidence, Evidence Report, Technology Assessment No. 47. AHRQ Publication No. 02-E016 (73). 
Only the studies scoring at least 50 of 100 on weighted scoring criteria were utilized for analysis.

Each study was evaluated by 2 physicians for stated criteria and any disagreements were resolved by a third physician.

If there was a conflict of interest with the reviewed manuscripts with authorship or any other type of conflict, the involved authors did not review the manuscripts for quality assessment or evidence synthesis.

If there were at least 4 randomized controlled trials available for a condition, observational studies were not included.

\section{Clinical Relevance}

Clinical relevance of the included studies was evaluated according to 5 questions recommended by the Cochrane Back Review Group $(36,79)$.

Table 3 shows the clinical relevance questions. Each question was scored positive (+) if the clinical relevance item was met, negative (-) if the item was not met, and unclear (?) if data were not available to answer the question.

\section{Analysis of Evidence}

Qualities analysis was conducted using 5 levels of evidence, ranging from Level I to III with 3 subcategories in Level II, as illustrated in Table 4 (80).

Grading recommendations were based on Guyatt et al's criteria as illustrated in Table 5 (81).

\section{Outcome of the Studies}

A study is judged to be positive if the epidural injection therapy was effective, either with a placebo control or active control in randomized trials. This indicates that the difference in the effect for the primary outcome measure was statistically significant at the conventional $5 \%$ level. In a negative study, there was no difference between the study treatments or no improvement from baseline. Further, the outcomes were judged at the reference point with positive or negative results reported at 3 months, 6 months, and 1 year.

For observational studies, a study was judged to be positive if the epidural injection therapy was effective, with outcomes reported at the reference

Table 3. Clinical relevance questions.

\begin{tabular}{|ll||}
\hline A) & Are the patients described in detail so that you can decide whether they are comparable to those that you see in your practice? \\
\hline B) & Are the interventions and treatment settings described well enough so that you can provide the same for your patients? \\
\hline C) & Were all clinically relevant outcomes measured and reported? \\
\hline D) & Is the size of the effect clinically important? \\
\hline E) & Are the likely treatment benefits worth the potential harms? \\
\hline
\end{tabular}

Source: Staal JB et al. Injection therapy for subacute and chronic low-back pain. Cochrane Database Syst Rev 2008; 3:CD001824 (36).

Table 4. Quality of evidence developed by USPSTF.

\begin{tabular}{|c|l||}
\hline I: & Evidence obtained from at least one properly randomized controlled trial \\
\hline II-1: & Evidence obtained from well-designed controlled trials without randomization \\
\hline II-2: & $\begin{array}{l}\text { Evidence obtained from well-designed cohort or case-control analytic studies, preferably from more than one center } \\
\text { or research group }\end{array}$ \\
\hline II-3: & $\begin{array}{l}\text { Evidence obtained from multiple time series with or without the intervention. Dramatic results in uncontrolled } \\
\text { experiments (such as the results of the introduction of penicillin treatment in the 1940s) could also be regarded as } \\
\text { this type of evidence }\end{array}$ \\
\hline III: & $\begin{array}{l}\text { Opinions of respected authorities, based on clinical experience descriptive studies and case reports or reports of } \\
\text { expert committees }\end{array}$ \\
\hline \hline
\end{tabular}

Adapted from the U.S. Preventive Services Task Force (USPSTF) (80). 
Table 5. Grading recommendations.

\begin{tabular}{|c|c|c|c|}
\hline $\begin{array}{c}\text { Grade of Recommendation/ } \\
\text { Description }\end{array}$ & $\begin{array}{c}\text { Benefit vs Risk and } \\
\text { Burdens }\end{array}$ & $\begin{array}{l}\text { Methodological Quality of } \\
\text { Supporting Evidence }\end{array}$ & Implications \\
\hline $\begin{array}{l}1 \mathrm{~A} / \text { strong recommendation, high- } \\
\text { quality evidence }\end{array}$ & $\begin{array}{l}\text { Benefits clearly outweigh } \\
\text { risk and burdens, or vice } \\
\text { versa }\end{array}$ & $\begin{array}{l}\text { RCTs without important limitations } \\
\text { or overwhelming evidence from } \\
\text { observational studies }\end{array}$ & $\begin{array}{l}\text { Strong recommendation, } \\
\text { can apply to most patients in } \\
\text { most circumstances without } \\
\text { reservation }\end{array}$ \\
\hline $\begin{array}{l}1 \mathrm{~B} / \text { strong recommendation, moder- } \\
\text { ate quality evidence }\end{array}$ & $\begin{array}{l}\text { Benefits clearly outweigh } \\
\text { risk and burdens, or vice } \\
\text { versa }\end{array}$ & $\begin{array}{l}\text { RCTs with important limitations } \\
\text { (inconsistent results, methodologi- } \\
\text { cal flaws, indirect, or imprecise) or } \\
\text { exceptionally strong evidence from } \\
\text { observational studies }\end{array}$ & $\begin{array}{l}\text { Strong recommendation, } \\
\text { can apply to most patients in } \\
\text { most circumstances without } \\
\text { reservation }\end{array}$ \\
\hline $\begin{array}{l}1 \mathrm{C} / \text { strong recommendation, low- } \\
\text { quality or very low-quality evidence }\end{array}$ & $\begin{array}{l}\text { Benefits clearly outweigh } \\
\text { risk and burdens, or vice } \\
\text { versa }\end{array}$ & Observational studies or case series & $\begin{array}{l}\text { Strong recommendation but } \\
\text { may change when higher qual- } \\
\text { ity evidence becomes available }\end{array}$ \\
\hline $\begin{array}{l}\text { 2A/weak recommendation, high- } \\
\text { quality evidence }\end{array}$ & $\begin{array}{l}\text { Benefits closely balanced } \\
\text { with risks and burden }\end{array}$ & $\begin{array}{l}\text { RCTs without important limitations } \\
\text { or overwhelming evidence from } \\
\text { observational studies }\end{array}$ & $\begin{array}{l}\text { Weak recommendation, best } \\
\text { action may differ depending } \\
\text { on circumstances or patients' } \\
\text { or societal values }\end{array}$ \\
\hline $\begin{array}{l}2 \mathrm{~B} / \text { weak recommendation, moderate- } \\
\text { quality evidence }\end{array}$ & $\begin{array}{l}\text { Benefits closely balanced } \\
\text { with risks and burden }\end{array}$ & $\begin{array}{l}\text { RCTs with important limitations } \\
\text { (inconsistent results, methodologi- } \\
\text { cal flaws, indirect, or imprecise) or } \\
\text { exceptionally strong evidence from } \\
\text { observational studies }\end{array}$ & $\begin{array}{l}\text { Weak recommendation, best } \\
\text { action may differ depending } \\
\text { on circumstances or patients' } \\
\text { or societal values }\end{array}$ \\
\hline $\begin{array}{l}2 \mathrm{C} / \text { weak recommendation, low-qual- } \\
\text { ity or very low-quality evidence }\end{array}$ & $\begin{array}{l}\text { Uncertainty in the esti- } \\
\text { mates of benefits, risks, } \\
\text { and burden; benefits, risk, } \\
\text { and burden may be closely } \\
\text { balanced }\end{array}$ & Observational studies or case series & $\begin{array}{l}\text { Very weak recommendations; } \\
\text { other alternatives may be } \\
\text { equally reasonable }\end{array}$ \\
\hline
\end{tabular}

Adapted from Guyatt G et al. Grading strength of recommendations and quality of evidence in clinical guidelines. Report from an American College of Chest Physicians task force. Chest 2006; 129:174-181 (81).

point with positive or negative results at 3 months, 6 months, and 1-year. Relief of 6 months or less was considered as short-term and relief of longer than 6 months was considered as long-term.

The data will be analyzed separately for disc herniation and/or radiculopathy, discogenic pain with predominantly low back pain, spinal stenosis, and post surgery syndrome.

Studies performed under fluoroscopy were given priority.

Observational studies were only included in the evidence synthesis if there were less than 4 randomized trials meeting inclusion criteria for each category as described above. If a study included more than one type of patient and the analysis in the study was considered separately for both conditions, that study was included for all the conditions.

\section{Results}

A literature search was carried out for caudal epidural injections as shown in Fig. 1.

As shown in Fig. 1, relevant reports evaluating caudal epidural injections included 18 randomized trials (68-71,82-95) and multiple prospective and retrospective evaluations $(65,66,96-115)$. 


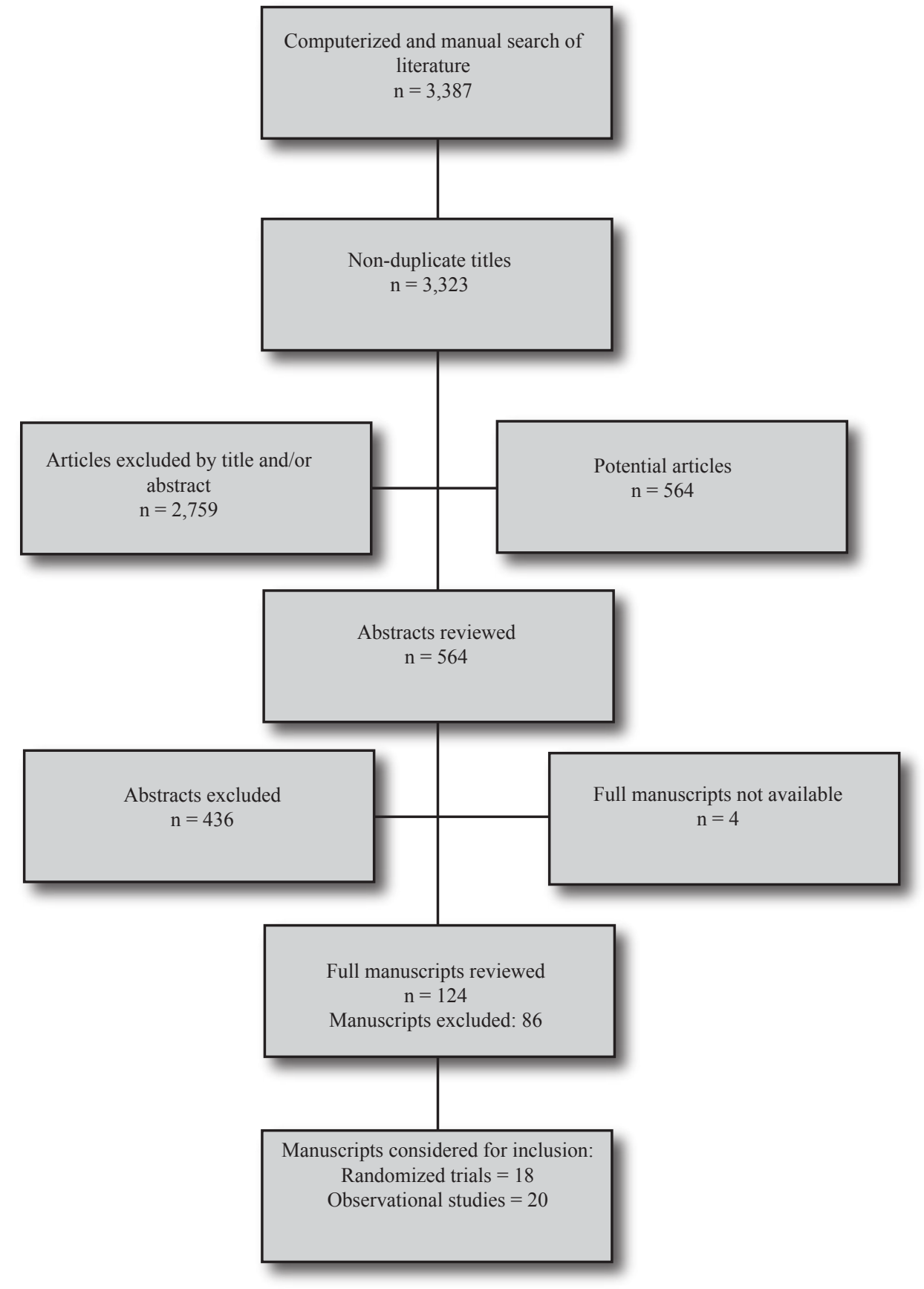

Fig. 1. The flow diagram illustrating randomized trials, observational studies, and systematic reviews evaluating caudal epidural injections. 
Table 6. Methodological assessment of randomized clinical trials evaluating the effectiveness of caudal epidural injections.

\begin{tabular}{|c|c|c|c|c|c|c|c|c|c|c|c|c|c|}
\hline & CRITERION & $\begin{array}{l}\text { Weighted } \\
\text { score } \\
\text { (points) }\end{array}$ & $\begin{array}{l}\text { Dashfield } \\
\text { et al }(82)^{*}\end{array}$ & $\begin{array}{l}\text { Mathews } \\
\text { et al (83) }\end{array}$ & $\begin{array}{c}\text { Breivik } \\
\text { et al } \\
(84)\end{array}$ & $\begin{array}{c}\text { Bush } \\
\text { and } \\
\text { Hillier } \\
(85)\end{array}$ & $\begin{array}{c}\text { Hesla } \\
\text { and } \\
\text { Breivik } \\
(89)\end{array}$ & \begin{tabular}{|l} 
Revel \\
et al \\
$(86)$
\end{tabular} & $\underset{\substack{\text { Manchikanti } \\
\text { et al }(68)^{*}}}{\mid}$ & $\mid \begin{array}{c}\text { Manchikanti } \\
\text { et al }(69)^{*}\end{array}$ & 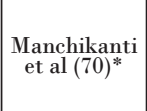 & $\underset{\text { et al }(71)^{*}}{\text { Manchikanti }}$ & $\begin{array}{c}\text { McGregor et } \\
\text { al (88) }\end{array}$ \\
\hline \multicolumn{14}{|c|}{ Study population } \\
\hline A & Homogeneity & 2 & 2 & 1 & 1 & 2 & 1 & 2 & 2 & 2 & 2 & 2 & - \\
\hline B & $\begin{array}{l}\text { Comparability of } \\
\text { relevant baseline } \\
\text { characteristics }\end{array}$ & 5 & 5 & 3 & 2 & 3 & 3 & 3 & 5 & 5 & 5 & 5 & - \\
\hline C & $\begin{array}{l}\text { Randomization pro- } \\
\text { cedure adequate }\end{array}$ & 4 & 4 & 4 & 4 & 2 & 4 & 1 & 5 & 5 & 5 & 5 & 1 \\
\hline $\mathrm{D}$ & $\begin{array}{l}\text { Drop-outs described } \\
\text { for each study group } \\
\text { separately }\end{array}$ & 3 & 3 & 3 & 3 & 3 & 3 & 3 & 3 & 3 & 3 & 3 & 2 \\
\hline $\mathrm{E}$ & $\begin{array}{l}<20 \% \text { loss for } \\
\text { follow-up }\end{array}$ & 2 & 2 & 2 & 2 & - & 2 & - & 2 & 2 & - & - & - \\
\hline & $\begin{array}{l}<10 \% \text { loss for } \\
\text { follow-up }\end{array}$ & 2 & 2 & 2 & 2 & - & 2 & - & - & - & - & - & - \\
\hline $\mathrm{F}$ & $\begin{array}{l}>50 \text { subject in the } \\
\text { smallest group }\end{array}$ & 8 & - & - & - & - & - & - & - & - & - & - & - \\
\hline & $\begin{array}{l}>100 \text { subjects in the } \\
\text { smallest group }\end{array}$ & 9 & - & - & - & - & - & - & - & - & - & - & - \\
\hline \multicolumn{14}{|c|}{ Interventions } \\
\hline G & $\begin{array}{l}\text { Interventions } \\
\text { included in protocol } \\
\text { and described }\end{array}$ & 10 & 10 & 10 & 10 & 10 & 10 & 10 & 10 & 10 & 10 & 10 & 4 \\
\hline $\mathrm{H}$ & Pragmatic study & 5 & 5 & - & 5 & - & 5 & 5 & 5 & 5 & 5 & 5 & 2 \\
\hline I & $\begin{array}{l}\text { Co-interventions } \\
\text { avoided or similar }\end{array}$ & 5 & - & 5 & 5 & 5 & 5 & - & 5 & 5 & 5 & 5 & - \\
\hline $\mathrm{J}$ & Placebo-controlled & 5 & - & 4 & 5 & 5 & - & - & - & - & - & - & - \\
\hline \multicolumn{14}{|c|}{ Effect } \\
\hline $\mathrm{K}$ & Patients blinded & 5 & 2 & 3 & 3 & 5 & 5 & 5 & 5 & 5 & 5 & 5 & 2 \\
\hline L & $\begin{array}{l}\text { Outcome measures } \\
\text { relevant }\end{array}$ & 10 & 6 & 4 & 6 & 5 & 3 & 10 & 10 & 10 & 10 & 10 & 10 \\
\hline M & $\begin{array}{l}\text { Blinded outcome } \\
\text { assessments }\end{array}$ & 10 & 2 & 10 & 10 & 5 & - & 10 & 5 & 5 & 5 & 5 & 5 \\
\hline $\mathrm{N}$ & $\begin{array}{l}\text { Follow-up period } \\
\text { adequate }\end{array}$ & 5 & 2 & 1 & - & 5 & 5 & 3 & 5 & 5 & 5 & 5 & 2 \\
\hline \multicolumn{14}{|c|}{ Data-presentation and analysis } \\
\hline $\mathrm{O}$ & $\begin{array}{l}\text { Intention-to-treat } \\
\text { analysis }\end{array}$ & 5 & - & 5 & 5 & - & 5 & 5 & 5 & 5 & 5 & 5 & - \\
\hline $\mathrm{P}$ & \begin{tabular}{|l} 
Frequencies of most \\
important outcomes \\
presented for each \\
treatment group
\end{tabular} & 5 & 5 & 5 & 5 & 5 & 5 & 5 & 5 & 5 & 5 & 5 & 5 \\
\hline & TOTAL SCORE & 100 & 50 & 62 & 68 & 55 & 58 & 62 & 72 & 72 & 70 & 70 & 33 \\
\hline
\end{tabular}

*Fluoroscopy used in performing caudal epidural injections.

Methodological criteria and scoring adapted from Koes BW et al. Efficacy of epidural steroid injections for low-back pain and sciatica: A systematic review of randomized clinical trials. Pain 1995; 63:279-288 (43). 


\section{Randomized Trials:}

\section{Methodologic Quality Assessment}

Methodologic quality assessment of the randomized clinical trials evaluating the effectiveness of caudal epidural injections is illustrated in Table 6. The methodological quality of criteria scores for the studies were variable from 33 to 72 . Of the 18 randomized trials, 11 met inclusion criteria for methodological assessment. Seven studies were excluded prior to the methodologic quality assessment due to the failure to meet the inclusion criteria $(87,90-95)$.

The study by Meadeb et al (87) was excluded due to short-term assessment of 120 days, even though, performed under fluoroscopy. Czarski (90) was excluded due to non-availability of analyzable data. Beliveau (91) was excluded due to a lack of data at 3 months. Anwar et al (92) was excluded due to a lack of appro- priate data. A study by Ackerman and Ahmad (93) was excluded due to short-term follow-up of 24 weeks, along with multiple deficiencies. Finally, Dincer et al (94) and Bronfort et al (95) were excluded due to a short-term follow-up.

After methodologic assessment of quality criteria, McGregor et al (88) scored less than 50, and thus was eliminated from the analysis.

\section{Clinical Relevance}

Clinical relevance of randomized clinical trials evaluating the effectiveness of caudal epidural steroid injections is illustrated in Table 7.

\section{Observational Studies}

Of the 10 observational studies meeting the inclusion criteria, 6 studies evaluating the effectiveness of caudal epidural injections for managing discogenic

Table 7. Clinical relevance of randomized clinical trials evaluating the effectiveness of caudal epidural injections.

\begin{tabular}{|c|c|c|c|c|c|c|c|c|c|c|}
\hline & $\begin{array}{l}\text { Dash- } \\
\text { field et } \\
\text { al }(82)^{*}\end{array}$ & $\begin{array}{l}\text { Mathews } \\
\text { et al (83) }\end{array}$ & $\begin{array}{l}\text { Breivik } \\
\text { et al } \\
(84)\end{array}$ & $\begin{array}{l}\text { Bush } \\
\text { and } \\
\text { Hillier } \\
(85)\end{array}$ & $\begin{array}{l}\text { Hesla } \\
\text { and } \\
\text { Breivik } \\
(89)\end{array}$ & $\begin{array}{l}\text { Revel } \\
\text { et al } \\
(86)\end{array}$ & $\begin{array}{l}\text { Manchikanti } \\
\text { et al }(68)^{*}\end{array}$ & $\begin{array}{l}\text { Manchikanti } \\
\text { et al (69)* }\end{array}$ & $\begin{array}{l}\text { Manchikanti } \\
\text { et al (70)* }\end{array}$ & $\begin{array}{l}\text { Manchikanti } \\
\text { et al }(71)^{*}\end{array}$ \\
\hline $\begin{array}{l}\text { A) Are the patients de- } \\
\text { scribed in detail so that } \\
\text { you can decide whether } \\
\text { they are comparable to } \\
\text { those that you see in } \\
\text { your practice? }\end{array}$ & + & + & + & + & + & + & + & + & + & + \\
\hline $\begin{array}{l}\text { B) Are the interven- } \\
\text { tions and treatment } \\
\text { settings described well } \\
\text { enough so that you can } \\
\text { provide the same for } \\
\text { your patients? }\end{array}$ & + & + & + & + & + & + & + & + & + & + \\
\hline $\begin{array}{l}\text { C) Were all clinically } \\
\text { relevant outcomes mea- } \\
\text { sured and reported? }\end{array}$ & + & + & + & + & + & + & + & + & + & + \\
\hline $\begin{array}{l}\text { D) Is the size of } \\
\text { the effect clinically } \\
\text { important? }\end{array}$ & + & + & + & + & + & + & + & + & + & + \\
\hline $\begin{array}{l}\text { E) Are the likely treat- } \\
\text { ment benefits worth the } \\
\text { potential harms? }\end{array}$ & + & + & + & + & + & + & + & + & + & + \\
\hline $\begin{array}{r}\text { TOTAL CRITERIA } \\
\text { MET } \\
\end{array}$ & $5 / 5$ & $5 / 5$ & $5 / 5$ & $5 / 5$ & $5 / 5$ & $5 / 5$ & $5 / 5$ & $5 / 5$ & $5 / 5$ & $5 / 5$ \\
\hline
\end{tabular}

+ = positive; - = negative; ? = unclear

${ }^{*}$ Fluoroscopy used in performing caudal epidural injections.

Scoring adapted from Staal JB et al. Injection therapy for subacute and chronic low-back pain. Cochrane Database Syst Rev 2008; 3:CD001824 (36). 
pain without radiculitis or disc herniation, post lumbar laminectomy syndrome, and spinal stenosis are illustrated in Table 8. Studies evaluating disc herniation were not included.

The methodologic assessment of observational studies $(65,66,102,106,116,118)$ evaluating the effectiveness of caudal epidural injections evaluating discogenic pain, spinal stenosis, and post lumbar laminectomy syndrome are illustrated in Table 8.

\section{Methodologic Review}

Of the 10 randomized trials meeting inclusion criteria, 6 studies evaluated disc herniation or radiculitis $(69,82-85,89)$. Of these, studies by Dashfield et al (82) and Manchikanti et al (69) were performed under fluoroscopy. Long-term information of more than 6 months was available in only 3 studies $(69,83,85)$. Three trials evaluated patients suffering with pain following failed back surgery syndrome $(70,86,89)$ whereas one of the 3 studies (95) evaluated a mixed population with greater than $50 \%$ or 36 of 69 patients with post lumbar laminectomy syndrome. Of these, only one study by Manchikanti et al (70) was performed under fluoroscopy. Long-term data was available in 2 of the 3 studies $(70,89)$, whereas only one study provided oneyear follow-up data (70). There was only one study in each group evaluating spinal stenosis (71) and discogenic low back pain (68), both performed under fluoroscopy and also with one-year follow-up.

Among the 11 observational studies, disc herniation or radiculitis were studied in 2 evaluations $(98,103)$, whereas the role of caudal epidural in chronic low back pain without radiculitis was studied in 2 studies $(65,66)$, and the role of caudal epidural steroids in spinal stenosis was evaluated in 7 studies $(100,104,110-114)$.

Of the 11 observational studies, the study Delport et al (104) failed to meet inclusion criteria for methodologic quality assessment. Yates (98) and Waldman (103) were not included as there were 6 randomized trials meeting the inclusion criteria. Thus, 6 observational studies underwent methodologic quality assessment with scores ranging from 46 to 76 of 100 . Consequently, 2 studies evaluating discogenic pain without radiculitis or disc herniation and 2 studies evaluating lumbar spinal stenosis met inclusion criteria $(96,112)$.

\section{Disc Herniation and Radiculitis}

Of all the available studies, 6 randomized trials $(69,82-85,89)$ met the inclusion criteria under this cat- egory. Dashfield et al (82) and Manchikanti et al (69) were studied under fluoroscopy. Long-term outcomes of more than 6 months were provided by Mathews et al (83), Manchikanti et al (69), Bush and Hillier (85), and Hesla and Breivik (89). Dashfield et al (82) and Breivik et al (84) provided only 6-month followup. Since 6 randomized trials met inclusion criteria for lumbar disc herniation and/or radiculitis, observational studies were not considered.

\section{Study Characteristics}

Table 9 illustrates the characteristics of the randomized trials in assessing caudal epidural injections in managing lumbar disc herniation and radiculitis.

Among the 2 studies utilizing fluoroscopy, Dashfield et al (82) compared the effectiveness of caudal steroid epidural with targeted steroid placement during spinal endoscopy for chronic sciatica in a prospective, randomized, double-blind trial, in 60 patients with symptom duration of 18 months. Patients in the caudal group underwent caudal epidural corticosteroid injection with a total of $10 \mathrm{~mL}$ of lidocaine $1 \%$ with $40 \mathrm{mg}$ of triamcinolone being injected into the epidural space. Patients in the epiduroscopy group underwent epiduroscopy performed by an experienced epiduroscopist with placement of steroid over the nerve root, which included $10 \mathrm{~mL}$ of lidocaine $1 \%$ with triamcinolone $40 \mathrm{mg}$. The epiduroscopy group also received infusion of 50 to $150 \mathrm{mg} \mathrm{mL}$ of sodium chloride solution. If adhesions were encountered around the painful nerve root, an attempt was made to break the adhesions down using saline boluses or by manipulating the endoscope. However, very little scar tissue was encountered in their patient population, as they never had previous surgery.

Patient assessments were carried out before treatment, and at 6 weeks, 3 months, and 6 months following treatment. Outcome instruments included SFMPQ and HAD scores. No significant differences were found between the groups for any of the measures at any time. However, there were significant differences within both groups compared with pretreatment values. For the caudal group, significant improvements were found for descriptive pain at 6 months; VAS at 6 weeks, 3 months, and 6 months; present pain intensity at 3 months and 6 months; anxiety at 6 weeks, 3 months, and 6 months; and depression at 6 months only. Caudal epidural injection was better than the epiduroscopy group where there were fewer significant changes. 
Caudal Epidural Injections in the Management of Chronic Low Back Pain

Table 8. Illustration of methodologic assessment of observational studies evaluating the effectiveness of caudal epidural injections.

\begin{tabular}{|c|c|c|c|c|c|c|c|}
\hline CRITERION & $\begin{array}{l}\text { Weighted } \\
\text { Score } \\
\text { (points) }\end{array}$ & $\begin{array}{l}\text { Manchikanti } \\
\text { et al }(65)^{*}\end{array}$ & $\begin{array}{l}\text { Manchikanti } \\
\text { et al }(66)^{*}\end{array}$ & $\begin{array}{l}\text { Ciocon et } \\
\text { al (96) }\end{array}$ & $\begin{array}{l}\text { Southern et } \\
\text { al }(110)^{*}\end{array}$ & $\begin{array}{c}\text { Barré et } \\
\text { al }(100)^{*}\end{array}$ & $\begin{array}{l}\text { Botwin et } \\
\text { al (112) }\end{array}$ \\
\hline 1. Study Question & 2 & 2 & 2 & 2 & 2 & 2 & 2 \\
\hline - Clearly focused and appropriate question & 2 & 2 & 2 & 2 & 2 & 2 & 2 \\
\hline 2. Study Population & 8 & 5 & 5 & 5 & 5 & 5 & 5 \\
\hline - Description of study population & 5 & 5 & 5 & 5 & 5 & 5 & 5 \\
\hline - Sample size justification & 3 & - & - & & - & - & - \\
\hline 3. Comparability of Subjects & 22 & 14 & 17 & 5 & 3 & 6 & 6 \\
\hline - Specific inclusion/exclusion criteria for all groups & 5 & 5 & 5 & 5 & - & 3 & 3 \\
\hline - Criteria applied equally to all groups & 3 & 3 & 3 & - & - & - & - \\
\hline $\begin{array}{l}\text { - Comparability of groups at baseline with } \\
\text { regard to disease status and prognostic factors }\end{array}$ & 3 & 3 & 3 & - & - & - & - \\
\hline $\begin{array}{l}\text { - Study groups comparable to non-participants } \\
\text { with regard to confounding factors }\end{array}$ & 3 & - & - & - & - & - & - \\
\hline - Use of concurrent controls & 5 & - & 3 & - & - & - & - \\
\hline $\begin{array}{l}\text { - Comparability of follow-up among groups at } \\
\text { each assessment }\end{array}$ & 3 & 3 & 3 & - & 3 & 3 & 3 \\
\hline 4. Exposure or Intervention & 11 & 11 & 11 & 7 & 8 & 8 & 8 \\
\hline - Clear definition of exposure & 5 & 5 & 5 & 5 & 5 & 5 & 5 \\
\hline - Measurement method standard, valid and reliable & 3 & 3 & 3 & 2 & 3 & 3 & 3 \\
\hline - Exposure measured equally in all study groups & 3 & 3 & 3 & - & - & - & - \\
\hline 5. Outcome measures & 20 & 15 & 15 & 15 & 15 & 15 & 15 \\
\hline - Primary/secondary outcomes clearly defined & 5 & 5 & 5 & 5 & 5 & 5 & 5 \\
\hline $\begin{array}{l}\text { - Outcomes assessed blind to exposure or } \\
\text { intervention }\end{array}$ & 5 & - & - & - & - & - & - \\
\hline $\begin{array}{l}\text { - Method of outcome assessment standard, valid } \\
\text { and reliable }\end{array}$ & 5 & 5 & 5 & 5 & 5 & 5 & 5 \\
\hline - Length of follow-up adequate for question & 5 & 5 & 5 & 5 & 5 & 5 & 5 \\
\hline 6. Statistical Analysis & 19 & 10 & 10 & 5 & 5 & 3 & 10 \\
\hline - Statistical tests appropriate & 5 & 5 & 5 & 5 & 3 & 3 & 5 \\
\hline - Multiple comparisons taken into consideration & 3 & 3 & 3 & - & - & - & 3 \\
\hline - Modeling and multivariate techniques appropriate & 2 & 2 & 2 & - & 2 & - & 2 \\
\hline - Power calculation provided & 2 & - & - & - & - & - & - \\
\hline - Assessment of confounding & 5 & - & - & - & - & - & - \\
\hline - Dose-response assessment if appropriate & 2 & - & - & - & - & - & - \\
\hline 7. Results & 8 & 6 & 6 & 8 & 2 & 2 & 5 \\
\hline $\begin{array}{l}\text { - Measure of effect for outcomes and appropri- } \\
\text { ate measure of precision }\end{array}$ & 5 & 3 & 3 & 5 & 2 & 2 & 5 \\
\hline - Adequacy of follow-up for each study group & 3 & 3 & 3 & 3 & - & - & - \\
\hline 8. Discussion & 5 & 5 & 5 & 5 & 3 & 5 & 5 \\
\hline $\begin{array}{l}\text { - Conclusions supported by results with possible } \\
\text { biases and limitations taken into consideration }\end{array}$ & & 5 & 5 & 5 & 5 & 5 & 5 \\
\hline 9. Funding or Sponsorship & 5 & 5 & 5 & 5 & 5 & 5 & 5 \\
\hline - Type and sources of support for study & & 5 & 5 & 5 & 5 & 5 & 5 \\
\hline TOTAL SCORE & 100 & 73 & 76 & 57 & 48 & 51 & 61 \\
\hline
\end{tabular}

${ }^{*}$ Fluoroscopically directed procedures.

Adapted and modified from West S et al. Systems to Rate the Strength of Scientific Evidence, Evidence Report, Technology Assessment No. 47. AHRQ Publication No. 02-E016 (73). 
Table 9. Characteristics of published studies of caudal epidural injections in managing disc herniation and radiculitis.

\begin{tabular}{|c|c|c|c|c|c|}
\hline Study/Methods & Participants & Intervention(s) & Outcome(s) & Result(s) & $\begin{array}{c}\text { Conclusion(s) } \\
\text { Short-term } \\
\text { relief } \leq 6 \mathrm{mos} \text {. } \\
\text { Long-term } \\
\text { relief }>6 \mathrm{mos} \text {. }\end{array}$ \\
\hline $\begin{array}{l}\text { Manchikanti et al } \\
2008(69) \\
\text { Randomized, } \\
\text { double-blind } \\
\text { equivalence trial }\end{array}$ & $\begin{array}{l}84 \text { patients were } \\
\text { assigned to one of } 2 \\
\text { groups; } \\
\text { Group I patients } \\
\text { received caudal epi- } \\
\text { dural injections with } \\
\text { an injection of local } \\
\text { anesthetic (lidocaine } \\
0.5 \% \text {, whereas, Group } \\
\text { II patients received } \\
\text { caudal epidural } \\
\text { injections with } 0.5 \% \\
\text { lidocaine } 9 \mathrm{~mL} \text { mixed } \\
\text { with } 1 \mathrm{~mL} \text { of steroid. }\end{array}$ & $\begin{array}{l}\text { Group I: caudal epidural } \\
\text { injections with injection } \\
\text { of local anesthetic (lido- } \\
\text { caine } 0.5 \% \text { ). } \\
\text { Group II: caudal epidu- } \\
\text { ral injections with } 0.5 \% \\
\text { lidocaine } 9 \mathrm{~mL} \text { mixed } \\
\text { with } 1 \mathrm{~mL} \text { of steroid. } \\
\text { Each injection was a total } \\
\text { volume of } 10 \mathrm{~mL} \text { ( } 10 \mathrm{~mL} \\
\text { of lidocaine } 0.5 \% \text { or } 9 \mathrm{~mL} \\
\text { of lidocaine with } 1 \mathrm{~mL} \mathrm{of} \\
\text { steroid), followed by } 2 \mathrm{~mL} \\
\text { of } 0.9 \% \text { sodium chloride } \\
\text { solution as a flush. }\end{array}$ & $\begin{array}{l}\text { Assessments: } 3 \\
\text { mos., } 6 \text { mos., and } \\
12 \text { mos. } \\
\text { Outcome instru- } \\
\text { ments: NRS, ODI, } \\
\text { employment status, } \\
\text { and opioid intake. }\end{array}$ & $\begin{array}{l}\text { The percentage of patients } \\
\text { with significant pain relief of } \\
50 \% \text { or greater at } 12 \text { months } \\
\text { was } 79 \% \text { in Group I and } \\
81 \% \text { in Group II. Reduction } \\
\text { of Oswestry scores of at least } \\
40 \% \text { was seen in } 83 \% \text { of the } \\
\text { patients in Group I and } 91 \% \\
\text { in Group II. } \\
\text { The overall average proce- } \\
\text { dures per year were } 3.9 \pm \\
1.26 \text { in Group I and } 3.6 \pm \\
1.08 \text { in Group II with an av- } \\
\text { erage total relief per year of } \\
35.2 \pm 17.18 \text { weeks in Group } \\
\text { I and } 35.9 \pm 15.34 \text { weeks in } \\
\text { Group II over a period of } 52 \\
\text { weeks. }\end{array}$ & $\begin{array}{l}\text { Positive short- } \\
\text { term and long- } \\
\text { term relief }\end{array}$ \\
\hline $\begin{array}{l}\text { Dashfield et al } \\
2005(82) \\
\text { Prospective, ran- } \\
\text { domized, double- } \\
\text { blind trial }\end{array}$ & $\begin{array}{l}60 \text { patients with a } \\
6-18 \text { months history } \\
\text { of sciatica to either } \\
\text { targeted epidural local } \\
\text { anaesthetic and ste- } \\
\text { roid placement with } \\
\text { a spinal endoscope } \\
\text { or caudal epidural } \\
\text { local anaesthetic and } \\
\text { steroid treatment. }\end{array}$ & $\begin{array}{l}\text { Corticosteroid injection } \\
\text { with a total of } 10 \mathrm{~mL} \text { of } \\
\text { lidocaine } 1 \% \text { with } 40 \mathrm{mg} \\
\text { of triamcinolone. } \\
\text { Epiduroscopy group: } \\
\text { delivery of the medica- } \\
\text { tion over the painful } \\
\text { nerve root with } 10 \mathrm{~mL} \text { of } \\
\text { lidocaine } 1 \% \text { with } 40 \mathrm{mg} \\
\text { of triamcinolone. }\end{array}$ & $\begin{array}{l}\text { Assessments: } 6 \\
\text { wks, } 3 \text { mos, and } \\
6 \text { mos. } \\
\text { Outcome instru- } \\
\text { ments: SF-MPQ } \\
\text { and HAD. }\end{array}$ & $\begin{array}{l}\text { Caudal group: significant } \\
\text { improvements were found } \\
\text { for descriptive pain at } 6 \\
\text { mos; VAS at } 6 \text { wks, } 3 \text { mos, } \\
\text { and } 6 \text { months; present pain } \\
\text { intensity at } 3 \text { mos and } 6 \\
\text { mos; anxiety at } 6 \text { wks, } 3 \\
\text { mos, and } 6 \text { mos; and depres- } \\
\text { sion at } 6 \text { mos only. }\end{array}$ & $\begin{array}{l}\text { Positive short- } \\
\text { term relief. } \\
\text { Long-term relief } \\
\text { information not } \\
\text { available }\end{array}$ \\
\hline $\begin{array}{l}\text { Bush and Hillier } \\
1991 \text { (85) } \\
\text { Randomized, } \\
\text { double-blind trial }\end{array}$ & $\begin{array}{l}23 \text { patients with } \\
\text { lumbar nerve root } \\
\text { compromise random- } \\
\text { ized into } 2 \text { groups. }\end{array}$ & $\begin{array}{l}\text { Experimental: } 25 \mathrm{~mL}: 80 \\
\text { mg triamcinolone ace- } \\
\text { tonide } \pm 0.5 \% \text { procaine } \\
\text { hydrochloride }(\mathrm{n}=12) \text {; } \\
\text { Control: } 25 \mathrm{~mL} \text { normal } \\
\text { saline ( } \mathrm{n}=11) \text {. Frequency: } \\
2 \text { caudal injections, the } \\
\text { first after admission to } \\
\text { the trial and a second } \\
\text { after } 2 \text { wks. }\end{array}$ & $\begin{array}{l}\text { Timing: } 4 \text { wks. and } \\
\text { at } 1 \text { year. } \\
\text { Outcome mea- } \\
\text { sures: } 1 \text {. Effect on } \\
\text { lifestyle; } 2 \text {. Back } \\
\text { and leg pain; } 3 \text {. } \\
\text { Angle of positive } \\
\text { SLR. }\end{array}$ & $\begin{array}{l}\text { Significantly better results } \\
\text { with pain and SLR in experi- } \\
\text { mental group in short-term. } \\
\text { Pain not significantly dif- } \\
\text { ferent but SLR significantly } \\
\text { better for long-term relief. }\end{array}$ & $\begin{array}{l}\text { Positive short- } \\
\text { term and long- } \\
\text { term relief }\end{array}$ \\
\hline $\begin{array}{l}\text { Mathews et al } \\
1987 \text { (83) } \\
\text { Randomized, } \\
\text { double- blind } \\
\text { trial }\end{array}$ & $\begin{array}{l}57 \text { patients with } \\
\text { sciatica with a single } \\
\text { root compression } \\
\text { Experimental group: } \\
\text { male/female: } 19 / 4 \text {, } \\
\text { median duration of } \\
\text { pain: } 4 \text { wks. Control } \\
\text { group: male/female: } \\
\text { 24/10, median dura- } \\
\text { tion of pain: } 4 \text { wks. }\end{array}$ & $\begin{array}{l}\text { Experimental: } 20 \mathrm{~mL} \\
\text { bupivacaine } 0.125 \% \pm 2 \\
\mathrm{~mL}(80 \mathrm{mg}) \text { methylpred- } \\
\text { nisolone acetate ( } \mathrm{n}=23 \text { ). } \\
\text { Control: } 2 \mathrm{~mL} \text { lignocaine } \\
\text { (over the sacral hiatus } \\
\text { or into a tender spot) } \\
\text { ( } \mathrm{n}=34) \text {. Frequency: fort- } \\
\text { nightly intervals, up to } 3 \\
\text { times as needed. }\end{array}$ & $\begin{array}{l}\text { Timing: } 2 \text { wks, } 1 \text {, } \\
3,6 \text {, and } 12 \text { mos. } \\
\text { Outcome } \\
\text { measures: pain } \\
\text { (recovered vs not } \\
\text { recovered), range } \\
\text { of movement, } \\
\text { straight leg rais- } \\
\text { ing, neurologic } \\
\text { examination. }\end{array}$ & $\begin{array}{l}\text { There was no signifi- } \\
\text { cant difference between } \\
\text { experimental and control } \\
\text { group with short-term relief } \\
(67 \% \text { vs } 56 \%) \text {. After } 3 \text { mos., } \\
\text { pts in experimental group } \\
\text { reported significantly more } \\
\text { pain-free than in control } \\
\text { group. }\end{array}$ & $\begin{array}{l}\text { Negative short- } \\
\text { term and positive } \\
\text { long-term relief }\end{array}$ \\
\hline
\end{tabular}


Caudal Epidural Injections in the Management of Chronic Low Back Pain

Table 9 (cont.). Characteristics of published studies of caudal epidural injections in managing disc herniation and radiculitis.

\begin{tabular}{|c|c|c|c|c|c|}
\hline Study/Methods & Participants & Intervention(s) & Outcome(s) & Result(s) & $\begin{array}{c}\text { Conclusion(s) } \\
\text { Short-term } \\
\text { relief } \leq 6 \mathrm{mos} . \\
\text { Long-term } \\
\text { relief }>6 \mathrm{mos} \text {. }\end{array}$ \\
\hline $\begin{array}{l}\text { Hesla and Breivik } \\
1979(89) \\
\text { Randomized, } \\
\text { double-blind trial } \\
\text { with crossover } \\
\text { design }\end{array}$ & $\begin{array}{l}69 \text { patients with } \\
\text { incapacitating chronic } \\
\text { low back pain and } \\
\text { sciatica. } \\
36 \text { of } 69 \text { previously } \\
\text { been operated on for } \\
\text { herniated disc. } \\
26 \text { similar patients } \\
\text { without previous back } \\
\text { surgery were treated } \\
\text { in a double-blind trial } \\
\text { with } 3 \text { lumbar epidu- } \\
\text { ral injections. }\end{array}$ & $\begin{array}{l}26 \text { patients without } \\
\text { previous back surgery } \\
\text { treated in a double-blind } \\
\text { trial by } 3 \text { caudal epidural } \\
\text { injections of bupivacaine } \\
\text { and depomethylpred- } \\
\text { nisolone } 80 \text { mg and a } \\
\text { placebo intramuscular } \\
\text { injection, or caudal } \\
\text { epidural bupivacaine and } \\
\text { depomethylprednisolone } \\
\text { given intramuscularly. }\end{array}$ & $\begin{array}{l}\text { Outcome mea- } \\
\text { sures: significant } \\
\text { improvement to } \\
\text { return to work or } \\
\text { to be retrained } \\
\text { for another } \\
\text { occupation. }\end{array}$ & $\begin{array}{l}34 \text { of the } 58 \text { pts }(59 \%) \\
\text { receiving caudal epidural } \\
\text { injections of bupivacaine } \\
\text { and depomethylpred- } \\
\text { nisolone showed significant } \\
\text { improvement. } \\
12 \text { of } 49 \text { pts ( } 25 \%) \text { who re- } \\
\text { ceived bupivacaine followed } \\
\text { by saline improved. } \\
50 \% \text { of previously operated } \\
\text { patients and } 70-80 \% \text { of pa- } \\
\text { tients without previous back } \\
\text { surgery obtained significant } \\
\text { pain relief. }\end{array}$ & $\begin{array}{l}\text { Positive short- } \\
\text { term and long- } \\
\text { term relief }\end{array}$ \\
\hline $\begin{array}{l}\text { Breivik et al } 1976 \\
\text { (84) Random- } \\
\text { ized, double- } \\
\text { blind trial }\end{array}$ & $\begin{array}{l}35 \text { patients with inca- } \\
\text { pacitating chronic low } \\
\text { back pain and sciatica. } \\
\text { Diagnosis based on } \\
\text { radiculopathy: arach- } \\
\text { noiditis ( } \mathrm{n}=8) \text {, no } \\
\text { abnormality ( } \mathrm{n}=11) \text {, } \\
\text { inconclusive findings } \\
(\mathrm{n}=5) \text {. Duration: } \\
\text { several mos to several } \\
\text { yrs. }\end{array}$ & $\begin{array}{l}\text { Caudal epidural injection: } \\
\text { Experimental: } 20 \mathrm{~mL} \\
\text { bupivacaine } 0.25 \% \text { with } \\
80 \mathrm{mg} \text { depomethylpred- } \\
\text { nisone ( } \mathrm{n}=16) \text { Placebo: } \\
20 \mathrm{~mL} \text { bupivacaine } 0.25 \% \\
\text { followed by } 100 \mathrm{~mL} \text { saline } \\
(\mathrm{n}=19) \text {. } \\
\text { Frequency: up to } 3 \text { injec- } \\
\text { tions at weekly intervals. }\end{array}$ & $\begin{array}{l}\text { Outcome } \\
\text { measures: } \\
\text { 1. Pain relief: } \\
\text { significant diminu- } \\
\text { tion of pain and/or } \\
\text { paresis to a degree } \\
\text { that enabled return } \\
\text { to work. } \\
\text { 2. Objective } \\
\text { improvement: sen- } \\
\text { sation, Lasègue's } \\
\text { test, paresis, } \\
\text { spinal reflexes, } \\
\text { and sphincter } \\
\text { disorders. }\end{array}$ & $\begin{array}{l}56 \% \text { of the pts reported } \\
\text { considerable pain relief in } \\
\text { experimental group com- } \\
\text { pared to } 26 \% \text { of the pts in } \\
\text { the placebo group. }\end{array}$ & $\begin{array}{l}\text { Positive short- } \\
\text { term relief. } \\
\text { Long-term relief } \\
\text { information not } \\
\text { available }\end{array}$ \\
\hline
\end{tabular}

Manchikanti et al (69) in a randomized, doubleblind equivalence trial, published preliminary results in 84 patients with 42 patients in each group of local anesthetic with or without steroid. The study consists of 60 patients in each group with Group I patients receiving caudal epidural injections with local anesthetic of lidocaine $0.5 \%$ preservative free, whereas Group II patients received caudal epidural injections with $0.5 \%$ lidocaine, $9 \mathrm{~mL}$, mixed with $1 \mathrm{~mL}$ of steroid. Repeat caudal epidural injections were provided based on the response to prior caudal epidural injections evaluated by improvement in physical and functional status. Multiple outcome measures were utilized with measurements of pain outcomes, employment status, and opioid intake assessed at 3 months, 6 months, and 12 months post-treatment. Significant pain relief was established as $50 \%$ or more reduction in numeric rating scale (NRS) from baseline, whereas significant improvement in function was described as at least a $40 \%$ reduction in Oswestry Disability Index (ODI). Sample size justification was provided for preliminary analysis and intent-to-treat analysis was performed. This report showed significant pain relief ( $\geq 50 \%$ ) in $79 \%$ to $81 \%$ of the patients with significant improvement in functional status $(40 \%$ or greater reduction in Oswestry scores) in $83 \%$ to $91 \%$ of the patients at the end of one-year follow-up with no significant differences noted with or without steroids. The overall average 
procedures per year were 3 to 4 with an average total relief per year of 35 to 36 weeks over a period of 52 weeks. Opioid intake and employment also showed significant improvement. The importance of this study lies in the fact that it is the practice of contemporary interventional pain management under fluoroscopy in a private practice setting with a randomized doubleblind design as an equivalence trial. The results of this study are generalizable to interventional pain management to populations in the United States.

\section{Effectiveness}

Of the 6 randomized trials, 5 studies were judged to be positive for short-term relief $(69,82-85)$. Only 4 trials $(69,83,85,89)$ reported positive results with longterm follow-up of more than 6 months. Surprisingly, Mathews et al (83) showed negative short-term relief, however, positive long-term relief. The results in 2 studies utilizing fluoroscopy $(69,82)$ were superior to blind epidural injections. Interestingly, both stud- ies $(69,82)$ were performed and published after 2000 , whereas the other 4 studies were published in 1976 (84), 1979 (89), 1987 (83), and 1991 (85). Table 10 illustrates the results of randomized trials of effectiveness of caudal epidural steroid injections in managing disc herniation and radiculitis.

\section{Post Surgery Syndrome}

Of the 10 randomized trials included for the analysis (Table 11), 3 studied the effectiveness of caudal epidural injections in post surgery syndrome and all of them met inclusion criteria based on methodologic quality assessment scores $(70,86,89)$. Only one study by Manchikanti et al (70) was performed under fluoroscopy. Of these, 2 studies $(70,89)$ provided outcomes of longer than 6 months. Revel et al (86) and Manchikanti et al (70) studied only post lumbar laminectomy syndrome patients whereas Hesla and Breivik (89) studied 36 of 69 patients previously operated for herniated disc. There were no observational studies performed

Table 10. Results of randomized trials of effectiveness of caudal epidural steroid injections in managing pain of lumbar disc herniation/radiculitis.

\begin{tabular}{|c|c|c|c|c|c|c|c|c|}
\hline \multirow[b]{2}{*}{ Study } & \multirow[b]{2}{*}{$\begin{array}{c}\text { Study } \\
\text { Characteristics }\end{array}$} & \multirow[b]{2}{*}{$\begin{array}{l}\text { Methodological } \\
\text { Quality Scoring }\end{array}$} & \multirow[b]{2}{*}{ Participants } & \multicolumn{3}{|c|}{ Pain Relief } & \multicolumn{2}{|c|}{ Results } \\
\hline & & & & 3 mos. & 6 mos. & 12 mos. & $\begin{array}{c}\text { Short-term } \\
\text { relief } \leq 6 \\
\text { mos. }\end{array}$ & $\begin{array}{c}\text { Long- } \\
\text { term } \\
\text { relief }>6 \\
\text { mos. }\end{array}$ \\
\hline $\begin{array}{l}\text { Manchikanti } \\
\text { et al } 2008 \\
(69)^{*}\end{array}$ & RA, DB & 72 & 84 & $81 \%$ & $86 \%$ & $\begin{array}{l}79 \% \text { to } \\
81 \%\end{array}$ & $\mathrm{P}$ & $\mathrm{P}$ \\
\hline $\begin{array}{l}\text { Dashfield et al } \\
2005(82)^{*}\end{array}$ & RA, DB & 50 & $\begin{array}{c}\text { Caudal }=30 \\
\text { Endoscopy }=30\end{array}$ & SI & SI & NA & $\mathrm{P}$ & NA \\
\hline $\begin{array}{l}\text { Bush and } \\
\text { Hillier } 1991 \\
\text { (85) }\end{array}$ & RA, DB & 55 & 23 & SI & NSI & NSI & $\mathrm{P}$ & $\mathrm{N}$ \\
\hline $\begin{array}{l}\text { Mathews et al } \\
1987 \text { (83) }\end{array}$ & RA, DB & 62 & $\begin{array}{l}\mathrm{C}=34 \\
\mathrm{~T}=23\end{array}$ & SI & SI & SI & $\mathrm{N}$ & $\mathrm{P}$ \\
\hline $\begin{array}{l}\text { Hesla and } \\
\text { Breivik } 1979 \\
\text { (89) }\end{array}$ & RA, DB & 58 & $\begin{array}{c}69 \text { patients: } \\
\text { crossover } \\
\text { design }\end{array}$ & $\begin{array}{c}77 \% \text { vs } \\
29 \%\end{array}$ & $\begin{array}{c}59 \% \text { vs } \\
25 \%\end{array}$ & $\begin{array}{l}59 \% \text { vs } \\
25 \%\end{array}$ & $\mathrm{P}$ & $\mathrm{P}$ \\
\hline $\begin{array}{l}\text { Breivik et al } \\
1976(84)\end{array}$ & RA, DB & 68 & $\begin{array}{l}\mathrm{C}=19 \\
\mathrm{~T}=16\end{array}$ & $\begin{array}{c}20 \% \text { vs } \\
50 \%\end{array}$ & $\begin{array}{c}20 \% \text { vs } \\
50 \%\end{array}$ & NA & $\mathrm{P}$ & NA \\
\hline
\end{tabular}

${ }^{*}$ Indicates use of fluoroscopy

$\mathrm{RA}=$ randomized $\mathrm{DB}=$ double blind $; \mathrm{C}=$ control $\mathrm{T}=$ treatment $\mathrm{NA}=$ not available; $\mathrm{SI}=$ significant improvement NSI = no significant improvement; vs = versus; $\mathrm{P}=$ positive $\mathrm{N}=$ negative 
in this category for inclusion with caudal epidural with or without steroids.

\section{Study Characteristics}

Table 11 shows the characteristics of published studies of caudal epidural injections in managing chronic low back or lower extremity pain of post surgery syndrome.
The only fluoroscopic study by Manchikanti et al (70) evaluated 40 patients in a randomized, doubleblind equivalence trial with an objective to evaluate the effectiveness of caudal epidural injections in patients with chronic low back and lower extremity pain after surgical intervention with post lumbar surgery syndrome. The results were preliminary from an expected study of 120 patients including 40 patients complet-

Table 11. Description of randomized trials in managing post-surgery syndrome with caudal epidural injections.

\begin{tabular}{|c|c|c|c|c|c|}
\hline Study/Methods & Participants & Intervention(s) & Outcome(s) & Result(s) & $\begin{array}{l}\text { Conclusion(s) } \\
\text { Short-term } \\
\text { relief } \leq 6 \mathrm{mos} \text {. } \\
\text { Long-term } \\
\text { relief }>6 \mathrm{mos} \text {. }\end{array}$ \\
\hline $\begin{array}{l}\text { Manchikanti et al } \\
2008(70) \\
\text { Randomized, } \\
\text { double-blind } \\
\text { equivalence trial }\end{array}$ & $\begin{array}{l}40 \text { patients with } \\
\text { chronic low back } \\
\text { and lower extremity } \\
\text { pain after surgical } \\
\text { intervention with } \\
\text { post lumbar surgery } \\
\text { syndrome. }\end{array}$ & $\begin{array}{l}\text { Group I patients received } \\
\text { caudal epidural injections with } \\
\text { local anesthetic (lidocaine } \\
0.5 \% \text { ), whereas Group II } \\
\text { patients received caudal } \\
\text { epidural injections with } 0.5 \% \\
\text { lidocaine } 9 \mathrm{~mL} \text { mixed with } 1 \\
\text { mL ( } 6 \mathrm{mg} \text { ) of non-particulate } \\
\text { Celestone. }\end{array}$ & $\begin{array}{l}\text { Timing: } 3 \text { mos., } \\
6 \text { mos., and } 12 \\
\text { mos. } \\
\text { Outcome } \\
\text { measures: } \\
\text { NRS, ODI, } \\
\text { employment } \\
\text { status and } \\
\text { opioid intake. }\end{array}$ & $\begin{array}{l}\text { Significant pain relief ( } \geq \\
50 \% \text { ) in } 60 \% \text { to } 70 \% \text { of } \\
\text { the patients. } \\
\text { Functional assessment } \\
\text { showed significant } \\
\text { improvement with at least } \\
40 \% \text { reduction in Oswestry } \\
\text { scores in } 40 \% \text { to } 55 \% \text { of } \\
\text { the patients. } \\
\text { The average procedures } \\
\text { per year were } 3.4 \text { with an } \\
\text { average total relief per year } \\
\text { of } 31.7 \pm 19.10 \text { weeks in } \\
\text { Group I and } 26.2 \pm 18.34 \\
\text { weeks in Group II over a } \\
\text { period of } 52 \text { weeks. }\end{array}$ & $\begin{array}{l}\text { Positive short- } \\
\text { term and long- } \\
\text { term relief }\end{array}$ \\
\hline $\begin{array}{l}\text { Revel et al } 1996 \\
(86) \\
\text { Randomized trial }\end{array}$ & $\begin{array}{l}60 \text { postlumbar } \\
\text { laminectomy pts } \\
\text { with chronic low } \\
\text { back pain. }\end{array}$ & $\begin{array}{l}\text { Forceful caudal injection: } \\
\text { Experimental: } 125 \mathrm{mg} \text { of } \\
\text { prednisolone acetate with } 40 \\
\mathrm{~mL} \text { of normal saline in the } \\
\text { treatment group. } \\
\text { Control: } 125 \mathrm{mg} \text { of } \\
\text { prednisolone. }\end{array}$ & $\begin{array}{l}\text { Timing: } 6 \\
\text { mos. Outcome } \\
\text { measures: pain } \\
\text { relief. }\end{array}$ & $\begin{array}{l}\text { The proportion of pts } \\
\text { relieved of sciatica was } \\
49 \% \text { in the forceful } \\
\text { injection group compared } \\
\text { to } 19 \% \text { in the control group } \\
\text { with significant difference. }\end{array}$ & $\begin{array}{l}\text { Positive short- } \\
\text { term relief and } \\
\text { long-term relief } \\
\text { in forceful } \\
\text { injection group }\end{array}$ \\
\hline $\begin{array}{l}\text { Hesla and Breivik } \\
1979(89) \\
\text { Randomized, } \\
\text { double-blind trial } \\
\text { with crossover } \\
\text { design }\end{array}$ & $\begin{array}{l}69 \text { patients with } \\
\text { incapacitating } \\
\text { chronic low back } \\
\text { pain and sciatica. } \\
36 \text { of } 69 \text { previously } \\
\text { been operated on for } \\
\text { herniated disc. } \\
26 \text { similar patients } \\
\text { without previous } \\
\text { back surgery, were } \\
\text { treated in a double- } \\
\text { blind trial by } 3 \\
\text { lumbar epidural } \\
\text { injections. }\end{array}$ & $\begin{array}{l}26 \text { patients without previous } \\
\text { back surgery treated in } \\
\text { a double-blind trial by } 3 \\
\text { caudal epidural injections } \\
\text { of bupivacaine and } \\
\text { depomethylprednisolone } \\
80 \text { mg and a placebo } \\
\text { intramuscular injection, or } \\
\text { caudal epidural bupivacaine } \\
\text { and depomethylprednisolone } \\
\text { given intramuscularly. }\end{array}$ & $\begin{array}{l}\text { Outcome } \\
\text { measures: } \\
\text { significant } \\
\text { improvement } \\
\text { to return to } \\
\text { work or to } \\
\text { be retrained } \\
\text { for another } \\
\text { occupation. }\end{array}$ & $\begin{array}{l}34 \text { of the } 58 \text { pts }(59 \%) \\
\text { receiving caudal epidural } \\
\text { injections of bupivacaine } \\
\text { and } \\
\text { depomethylprednisolone } \\
\text { showed significant } \\
\text { improvement. } \\
12 \text { of } 49 \text { pts }(25 \%) \text { who } \\
\text { received bupivacaine } \\
\text { followed by saline } \\
\text { improved. } \\
50 \% \text { of previously } \\
\text { operated patients and } 70- \\
80 \% \text { of patients without } \\
\text { previous back surgery } \\
\text { obtained significant pain } \\
\text { relief. }\end{array}$ & $\begin{array}{l}\text { Positive short- } \\
\text { term and long- } \\
\text { term relief }\end{array}$ \\
\hline
\end{tabular}


ing one year follow-up with justification of sample size in the subgroup analysis. They assigned patients into one of 2 groups with Group I patients receiving caudal epidural injections of local anesthetic (lidocaine $0.5 \%$ preservative free), whereas Group II patients received caudal epidural injections with $0.5 \%$ lidocaine, $9 \mathrm{~mL}$, mixed with $1 \mathrm{~mL}$ of non-particulate Celestone, $6 \mathrm{mg}$, under fluoroscopy. Multiple outcome measures were utilized including measurement of pain and disability, employment status, and opioid intake. Significant pain relief was described as a $50 \%$ or more reduction in NRS from baseline, whereas significant improvement and function was described as at least a $40 \%$ reduction in the ODI. In this study utilizing contemporary practice with fluoroscopy and in a private practice setting in a double-blind equivalence trial, preliminary results of one year showed significant pain relief ( $\geq 50 \%$ ) in $60 \%$ to $65 \%$ of the patients and functional improvement (greater than $40 \%$ reduction in ODI) in $55 \%$ to $70 \%$ of the patients with no significant differences between the groups at one-year follow-up. Patients in the study received overall 3 to 4 procedures in a year with an average total relief of 26 to 32 weeks of 52 weeks. However, there were significant withdrawals due to failure and separation into successful and failed groups. In the successful group, the total relief per year ranged from 35 to 44 weeks with an extremely low response in the failed subjects. Average relief per procedure was 10 to 14 weeks. Further, opioid intake was also reduced significantly at one-year follow-up. The advantages of this study include the fact that it is an equivalence trial performed in a private practice with the results generalizable to the interventional pain patient population across the country when performed fluoroscopically.

\section{Effectiveness}

Of the 3 randomized trials studying the effectiveness of caudal epidural steroid injections in post-surgery syndrome, all of them were shown to be positive for short and long-term relief $(70,86,89)$. Table 12 illustrates the results of randomized trials in managing chronic pain of post surgery syndrome with caudal epidural injections.

\section{Spinal Stenosis}

There was one randomized trial evaluating the role of caudal epidural injections in spinal stenosis (71). This study met inclusion criteria and was performed under fluoroscopy with 1-year follow-up.

There were 4 observational studies $(96,100,104$, 112) available with 2 meeting inclusion criteria.

\section{Study Characteristics}

Table 13 shows the characteristics of published reports of caudal epidural injections in managing spinal stenosis. Manchikanti et al (71) published preliminary results of a randomized equivalence trial of fluoroscopic caudal epidural injections in managing chronic low back pain secondary to spinal stenosis. The study included 40 patients with 20 patients in each group with justification of sample size. They utilized multiple outcome measures, included NRS, ODI, employment

Table 12. Results of randomized trials in managing low back pain of post-surgery syndrome with caudal epidural injections.

\begin{tabular}{|c|c|c|c|c|c|c|c|c|}
\hline \multirow[b]{2}{*}{ Study } & \multirow[b]{2}{*}{$\begin{array}{c}\text { Study } \\
\text { Characteristics }\end{array}$} & \multirow[b]{2}{*}{$\begin{array}{l}\text { Methodological } \\
\text { Quality Scoring }\end{array}$} & \multirow[b]{2}{*}{ Participants } & \multicolumn{3}{|c|}{ Pain Relief } & \multicolumn{2}{|c|}{ Results } \\
\hline & & & & 3 mos. & 6 mos. & 12 mos. & $\begin{array}{c}\text { Short-term } \\
\text { relief } \leq 6 \\
\text { mos. }\end{array}$ & $\begin{array}{c}\text { Long- } \\
\text { term } \\
\text { relief }>6 \\
\text { mos. }\end{array}$ \\
\hline $\begin{array}{c}\text { Manchikanti et } \\
\text { al } 2008(70)\end{array}$ & RA, DB & 70 & 40 & $\begin{array}{c}65 \% \text { to. } \\
70 \%\end{array}$ & $60 \%$ & $\begin{array}{l}60 \% \text { to } \\
65 \%\end{array}$ & $\mathrm{P}$ & $\mathrm{P}$ \\
\hline $\begin{array}{l}\text { Revel et al } \\
1996(86)\end{array}$ & RA & 62 & $\begin{array}{c}\text { Forceful injec- } \\
\text { tion }=29 \\
\text { Regular }=31\end{array}$ & NA & $\begin{array}{c}49 \% \text { vs } \\
19 \%\end{array}$ & NA & $\mathrm{P}$ & $\mathrm{P}$ \\
\hline $\begin{array}{c}\text { Hesla and } \\
\text { Breivik } 1979 \\
\text { (89) }\end{array}$ & $\mathrm{RA}, \mathrm{DB}$ & 58 & $\begin{array}{l}69 \text { patients: } \\
\text { crossover } \\
\text { design }\end{array}$ & $\begin{array}{c}77 \% \text { vs } \\
29 \%\end{array}$ & $\begin{array}{l}59 \% \text { vs } \\
25 \%\end{array}$ & $59 \%$ vs $25 \%$ & $\mathrm{P}$ & $\mathrm{P}$ \\
\hline
\end{tabular}

$\mathrm{RA}=$ randomized $\mathrm{DB}=$ double blind; $\mathrm{NA}=$ not available; $\mathrm{vs}=$ versus; $\mathrm{P}=$ positive; $\mathrm{N}=$ negative 
Table 13. Characteristics of published studies of caudal epidural injections in managing spinal stenosis

\begin{tabular}{|c|c|c|c|c|c|}
\hline Study/Methods & Participants & Intervention(s) & Outcome(s) & Result(s) & $\begin{array}{c}\text { Conclusion(s) } \\
\text { Short-term } \\
\text { relief } \leq 6 \mathrm{mos} . \\
\text { Long-term } \\
\text { relief }>6 \mathrm{mos} \text {. }\end{array}$ \\
\hline $\begin{array}{l}\text { Manchikanti et al } \\
2008 \text { (71) } \\
\text { Randomized, } \\
\text { double-blind } \\
\text { equivalence trial }\end{array}$ & $\begin{array}{l}40 \text { patients with } \\
\text { chronic low back } \\
\text { pain secondary to } \\
\text { spinal stenosis. }\end{array}$ & $\begin{array}{l}\text { Group I patients } \\
\text { receiving caudal } \\
\text { epidural injections } \\
\text { of local anesthetic } \\
\text { (lidocaine } 0.5 \% \text { ), } \\
\text { whereas Group II } \\
\text { patients received } \\
\text { caudal epidural in- } \\
\text { jections with } 0.5 \% \\
\text { lidocaine, } 9 \mathrm{~mL} \text {, } \\
\text { mixed with } 1 \mathrm{~mL} \\
\text { of non-particulate } \\
\text { Celestone. }\end{array}$ & $\begin{array}{l}\text { Timing: } 3 \text { mos., } 6 \\
\text { mos., and } 12 \text { mos. } \\
\text { Outcome mea- } \\
\text { sures: NRS, ODI, } \\
\text { employment status } \\
\text { and opioid intake. }\end{array}$ & $\begin{array}{l}\text { Significant pain relief ( }>50 \% \text { ) } \\
\text { was demonstrated in } 55 \% \text { to } 65 \% \\
\text { of patients with functional status } \\
\text { improvement with } 40 \% \text { reduction } \\
\text { in ODI scores in } 55 \% \text { to } 80 \% \text { of } \\
\text { the patients. The overall average } \\
\text { procedures ranged from } 3 \text { to } 4 \\
\text { with an average total relief of } 23 \\
\text { to } 30 \text { weeks over a period of } 52 \\
\text { weeks. However, when the groups } \\
\text { were separated into failed groups } \\
\text { and successful groups, the results } \\
\text { improved somewhat with average } \\
\text { relief ranging from } 38 \text { to } 43 \text { weeks } \\
\text { over a period of one year with an } \\
\text { average relief of } 10 \text { to } 15 \text { weeks } \\
\text { per procedure in overall popula- } \\
\text { tion. There was also reduction of } \\
\text { opioid intake. }\end{array}$ & $\begin{array}{l}\text { Positive short and } \\
\text { long-term relief }\end{array}$ \\
\hline $\begin{array}{l}\text { Ciocon et al } 1994 \\
(96) \\
\text { Prospective } \\
\text { evaluation }\end{array}$ & $\begin{array}{l}30 \text { patients, } 76 \\
+/-6.7 \text { years of } \\
\text { age, with leg dis- } \\
\text { comfort with or } \\
\text { without back pain } \\
\text { and with lumbar } \\
\text { canal stenosis. }\end{array}$ & $\begin{array}{l}\text { Subjects received } \\
\text { a total of } 3 \text { doses } \\
\text { of } 0.5 \% \text { Xylocaine } \\
\text { with } 80 \mathrm{mg} \text { Depo- } \\
\text { Medrol into the } \\
\text { caudal epidural } \\
\text { space through the } \\
\text { sacral hiatus at } \\
\text { weekly intervals. }\end{array}$ & $\begin{array}{l}\text { The Roland 5-point } \\
\text { pain rating scale } \\
\text { was utilized before } \\
\text { and at 2-month } \\
\text { intervals up to } 10 \\
\text { months after the } \\
\text { CEB was admin- } \\
\text { istered. MRI was } \\
\text { used to identify the } \\
\text { degree of lumbar } \\
\text { canal stenosis. }\end{array}$ & $\begin{array}{l}\text { After CEB, the pain level changed } \\
\text { from } 3.43+/-0.82 \text { to } 1.5+/-0.86 \\
(P<0.0000) \text {, with a significant } \\
\text { relief of pain up to } 10 \text { months } \\
\text { (the end of observation). The du- } \\
\text { ration of pain relief ranged from } \\
4 \text { to } 10 \text { months }(P<0.0001) \text {. }\end{array}$ & $\begin{array}{l}\text { Positive short and } \\
\text { long-term relief }\end{array}$ \\
\hline $\begin{array}{l}\text { Barrè et al } 2004 \\
(100) \\
\text { Retrospective } \\
\text { evaluation }\end{array}$ & $\begin{array}{l}95 \text { patients } \\
\text { selected from } \\
\text { chart review } \\
\text { met inclusion } \\
\text { criteria. Eighty } \\
(84 \%) \text { completed } \\
\text { the follow-up } \\
\text { questionnaire by } \\
\text { mail or telephone } \\
\text { interview. Patients } \\
\text { received an aver- } \\
\text { age of } 1.6 \text { epidural } \\
\text { steroid injections. } \\
12 \text { patients } \\
\text { subsequently un- } \\
\text { derwent surgical } \\
\text { procedures. }\end{array}$ & $\begin{array}{l}\text { Fluoroscopi- } \\
\text { cally guided caudal } \\
\text { epidural injections } \\
\text { after failure of con- } \\
\text { servative care. }\end{array}$ & $\begin{array}{l}\text { Visual Numeric } \\
\text { Scale (VNS), } \\
\text { Roland-Morris } \\
\text { Disability Ques- } \\
\text { tionnaire (RMDQ), } \\
\text { North American } \\
\text { Spine Society } \\
\text { Patient Satisfac- } \\
\text { tion Index (NASS), } \\
\text { and subsequent } \\
\text { surgery. }\end{array}$ & $\begin{array}{l}\text { A VNS improvement of } 50 \% \text { or } \\
\text { greater was seen in } 35 \% \text { of pa- } \\
\text { tients. A functional improvement } \\
\text { of } 2 \text { points or greater was seen on } \\
\text { the RMDQ in } 36 \% \text { of patients. } \\
\text { Long-term success of treatment } \\
\text { was seen in } 35 \% \text { of patients. The } \\
\text { concurrent presence of degenera- } \\
\text { tive spondylolisthesis was the } \\
\text { only variable which was found to } \\
\text { have a significant positive cor- } \\
\text { relation with successful outcomes } \\
(P<0.009) \text {. }\end{array}$ & $\begin{array}{l}\text { Positive short and } \\
\text { long-term relief }\end{array}$ \\
\hline $\begin{array}{l}\text { Botwin et al } 2007 \\
\text { (112) } \\
\text { Prospective } \\
\text { evaluation }\end{array}$ & $\begin{array}{l}34 \text { patients with } \\
\text { bilateral radicular } \\
\text { pain from lumbar } \\
\text { spinal stenosis. }\end{array}$ & $\begin{array}{l}\text { Fluoroscopi- } \\
\text { cally guided caudal } \\
\text { epidural injections } \\
\text { after failure of con- } \\
\text { servative care. }\end{array}$ & $\begin{array}{l}\text { Visual analog } \\
\text { scale, patient } \\
\text { satisfaction scale, } \\
\text { standing/walking } \\
\text { tolerance scale } \\
\text { and Oswestry low } \\
\text { back pain disability } \\
\text { questionnaire. }\end{array}$ & $\begin{array}{l}65 \% \text { of patients at } 6 \text { weeks, } 62 \% \\
\text { at } 6 \text { months, and } 54 \% \text { at } 12 \\
\text { months had a successful out- } \\
\text { come, reporting at least a }>50 \% \\
\text { reduction between pre-injection } \\
\text { and post injection visual analog } \\
\text { pain scores. }\end{array}$ & $\begin{array}{l}\text { Positive short and } \\
\text { long-term relief }\end{array}$ \\
\hline
\end{tabular}


status, and opioid intake with assessment at 3 months, 6 months, and 12 months post-treatment. They defined significant pain relief as $50 \%$ or more, whereas significant improvement in disability score was defined as reduction of $40 \%$ or more. Patients were assigned randomly into 2 groups, with Group I patients receiving caudal epidural injections of local anesthetic (lidocaine $0.5 \%$ ), whereas Group II patients received caudal epidural injections with $0.5 \%$ lidocaine, $9 \mathrm{~mL}$, mixed with $1 \mathrm{~mL}$ of non-particulate Celestone.

Significant pain relief ( $\geq 50 \%$ ) was demonstrated in $55 \%$ to $65 \%$ of patients with functional status improvement with a $40 \%$ reduction in ODI scores in $55 \%$ to $80 \%$ of the patients. The overall average procedures ranged from 3 to 4 with an average total relief of 23 to 30 weeks over a period of 52 weeks. However, when the groups were separated into failed groups and successful groups, the results improved somewhat with average relief ranging from 38 to 43 weeks over a period of one year with an average relief of 10 to 15 weeks per procedure in overall population. There was also a reduction of opioid intake. Even though this is a small study, it was performed utilizing contemporary interventional pain management techniques under fluoroscopic evaluation with appropriate outcome parameters in a private practice setting, yet utilizing a randomization and double-blind design in an equivalence trial comparing local anesthetic and steroid. Thus, these results can be applied to populations across the United States. Further, this is the first randomized trial evaluating the role of caudal epidural injections in spinal stenosis.

Of the multiple fluoroscopically directed studies, 3 included caudal $(100,104,112)$, whereas 2 were caudal without fluoroscopy $(96,111)$. Botwin et al $(112)$ in a prospective evaluation evaluated 34 patients with bilateral radicular pain from lumbar spinal stenosis with fluoroscopically guided caudal epidural injections after failure of conservative care. They administered on average 2.2 injections per patient, all within 6 weeks of evaluation; $65 \%$ of the patients at 6 weeks, $62 \%$ at 6 months, and $54 \%$ at 12 months had a successful outcome, reporting at least a greater than $50 \%$ reduction between pre-injection and postinjection visual analog scale (VAS). They also reported significant improvement in multiple other scores including sitting, standing, and satisfaction. Barré et al (100) in a retrospective evaluation of long-term efficacy of fluoroscopically guided caudal epidural steroid injections for lumbar spinal stenosis evaluated 80 patients receiving at least one caudal epidural steroid injection between 1995 and 2002 with an average of 1.6 epidural steroid injections administered. They reported an improvement on the NRS of $50 \%$ or greater in $35 \%$ of patients with a functional improvement of 2 points or greater in 36 patients on a long-term basis.

Delport et al (104) in a retrospective outcome study reported the results of 140 patients, at or over the age of 55 years diagnosed with lumbar spinal stenosis, treated with either fluoroscopically guided transforaminal or caudal epidural steroid injections. Overall, they reported improvement at 2 months in $32 \%$ with $39 \%$ reporting less than 2 months of relief and with improvement in functional abilities in $53 \%$. Of these, 91 patients, or $65 \%$, received caudal epidural injections, whereas $59 \%$ of the patients received both. However, all 3 studies suffer from multiple flaws. Botwin et al (112) and Barré et al (100) both utilized one to 3 epidural injections within a short time period and expected persistent relief. Further, Delport et al (104) combined caudal and trans-

Table 14. Results of effectiveness in evaluation in managing spinal stenosis.

\begin{tabular}{|c|c|c|c|c|c|c|c|c|}
\hline \multirow[b]{2}{*}{ Study } & \multirow[b]{2}{*}{$\begin{array}{c}\text { Study } \\
\text { Characteristics }\end{array}$} & \multirow[b]{2}{*}{$\begin{array}{l}\text { Methodological } \\
\text { Quality Scoring }\end{array}$} & \multirow[b]{2}{*}{ Participants } & \multicolumn{3}{|c|}{ Pain Relief } & \multicolumn{2}{|c|}{ Results } \\
\hline & & & & $3 \mathrm{mos}$ & $6 \mathrm{mos}$ & $12 \mathrm{mos}$ & $\begin{array}{l}\text { Short- } \\
\text { term relief } \\
\leq 6 \mathrm{mos} \text {. }\end{array}$ & $\begin{array}{c}\text { Long-term } \\
\text { relief }>6 \\
\text { mos. }\end{array}$ \\
\hline $\begin{array}{l}\text { Manchikanti } \\
\text { et al } 2008 \text { (71) }\end{array}$ & RA, DB & 70 & 40 & $\begin{array}{c}50 \% \text { to } \\
65 \%\end{array}$ & $\begin{array}{c}60 \% \text { to } \\
65 \%\end{array}$ & $55 \%$ to $65 \%$ & $\mathrm{P}$ & $\mathrm{P}$ \\
\hline $\begin{array}{l}\text { Ciocon et al } \\
1994(96)\end{array}$ & $\mathrm{O}$ & 57 & 30 & SI & SI & NA & $\mathrm{P}$ & NA \\
\hline $\begin{array}{l}\text { Botwin et al } \\
2007(112)\end{array}$ & $\mathrm{O}$ & 61 & 34 & $65 \%$ & $62 \%$ & $54 \%$ & $\mathrm{P}$ & $\mathrm{P}$ \\
\hline
\end{tabular}

$\mathrm{RA}=$ randomized; $\mathrm{O}=$ observational; $\mathrm{DB}=$ double blind; $\mathrm{NA}=$ not available; $\mathrm{SI}=$ significant improvement; vs = versus; $\mathrm{P}=$ positive; $\mathrm{N}=$ negative 
foraminal epidural injections in multiple patients with a short-term follow-up. A series of 3 epidurals is an outdated procedural model, even though they utilized a contemporary approach with fluoroscopic utilization.

\section{Effectiveness}

The one randomized trial evaluating spinal stenosis with or without steroids with local anesthetic showed positive results for short- and long-term relief.

Observational studies also showed positive shortterm and long-term improvement.

Table 14 illustrates results of effectiveness of caudal epidural steroid injection in managing spinal stenosis.

\section{Discogenic Pain}

Predominant low back pain without disc herniation is considered as discogenic pain. Close attention was paid to the studies evaluating the effectiveness of caudal epidural injections in discogenic pain for inclusion criteria. One randomized trial (68) and 2 observational studies $(65,66)$ met inclusion criteria based on methodologic quality assessment and 2 of them $(66,68)$ had long-term follow-up of at least one year with methodologic quality criteria of 72,73 , and 76 .

\section{Study Characteristics}

Descriptive characteristics are demonstrated in Table 15.

Table 15. Study characteristics of randomized trials and observational studies in managing discogenic pain with caudal epidural steroid injections.

\begin{tabular}{|c|c|c|c|c|c|}
\hline Study/Methods & Participants & Intervention(s) & Outcome(s) & Result(s) & $\begin{array}{l}\text { Conclusion(s) } \\
\text { Short-term } \\
\text { relief } \leq 6 \mathrm{mos} . \\
\text { Long-term } \\
\text { relief }>6 \mathrm{mos} \text {. }\end{array}$ \\
\hline $\begin{array}{l}\text { Manchikanti et } \\
\text { al } 2008 \text { (68) } \\
\text { Randomized, } \\
\text { double-blind } \\
\text { equivalence trial }\end{array}$ & $\begin{array}{l}64 \text { patients with } \\
\text { chronic low back } \\
\text { pain of discogenic } \\
\text { origin, without } \\
\text { disc herniation or } \\
\text { radiculitis. }\end{array}$ & $\begin{array}{l}\text { Group I patients received } \\
\text { caudal epidural injections } \\
\text { with local anesthetic of } \\
\text { lidocaine } 0.5 \% \text { preserva- } \\
\text { tive free, whereas Group } \\
\text { II patients received } \\
\text { caudal epidural injections } \\
\text { with } 0.5 \% \text { lidocaine, } 9 \\
\text { mL, mixed with } 1 \mathrm{~mL} \text { of } \\
\text { steroid. }\end{array}$ & $\begin{array}{l}\text { Timing: } 3 \text { mos., } 6 \\
\text { mos., and } 12 \text { mos. } \\
\text { Outcome: average } \\
\text { pain, functional } \\
\text { status, psychologi- } \\
\text { cal status, narcotic } \\
\text { intake, and employ- } \\
\text { ment status. }\end{array}$ & $\begin{array}{l}\text { Significant pain relief ( } \geq \\
50 \% \text { ) was demonstrated in } \\
72 \% \text { to } 81 \% \text { of patients and } \\
\text { functional status improve- } \\
\text { ment was demonstrated by } \\
\text { a reduction of } 40 \% \text { in the } \\
\text { ODI scores in } 81 \% \text { of the } \\
\text { patients. The overall average } \\
\text { procedures per year were } 3.6 \\
\pm 1.05 \text { in Group I and } 3.9 \\
\pm 1.33 \text { in Group II with an } \\
\text { average total relief per year of } \\
32.3 \pm 16.93 \text { weeks in Group } \\
\text { I and } 30.7 \pm 17.94 \\
\text { weeks in Group II over a } \\
\text { period of } 52 \text { weeks. }\end{array}$ & $\begin{array}{l}\text { Positive short- } \\
\text { term and long- } \\
\text { term relief }\end{array}$ \\
\hline $\begin{array}{l}\text { Manchikanti et } \\
\text { al } 2001 \text { (66) } \\
\text { Randomized } \\
\text { trial with con- } \\
\text { venient control } \\
\text { group }\end{array}$ & $\begin{array}{l}70 \text { pts after failed } \\
\text { conservative } \\
\text { management with } \\
\text { physical therapy, } \\
\text { chiropractic, and } \\
\text { medication therapy. } \\
\text { All pts were shown } \\
\text { to be negative for } \\
\text { facet joint pain. }\end{array}$ & $\begin{array}{l}\text { Group I : no treatment } \\
\text { Group II: local anesthetic } \\
\text { and Sarapin total of } 20 \\
\mathrm{~mL} \text { with } 10 \mathrm{~mL} \text { each. } \\
\text { Group III: } 10 \mathrm{~mL} \text { of local } \\
\text { anesthetic and } 6 \mathrm{mg} \text { of } \\
\text { betamethasone. }\end{array}$ & $\begin{array}{l}\text { Timing: } 2 \text { wks, } 1 \\
\text { month, } 3 \text { mos., } 6 \\
\text { mos., and } 1 \text { year. } \\
\text { Outcome measures: } \\
\text { Average pain, physi- } \\
\text { cal health, mental } \\
\text { health, and func- } \\
\text { tional status. }\end{array}$ & $\begin{array}{l}\text { Average pain, physical health, } \\
\text { mental health, functional } \\
\text { status, narcotic intake, and } \\
\text { employment improved } \\
\text { significantly in Group II and } \\
\text { Group III at } 2 \text { wks, } 1 \text { month, } \\
3 \text { mos., } 6 \text { mos., and } 1 \text { year. }\end{array}$ & $\begin{array}{l}\text { Positive short- } \\
\text { term and long- } \\
\text { term relief }\end{array}$ \\
\hline $\begin{array}{l}\text { Manchikanti et } \\
\text { al } 2002(65) \\
\begin{array}{l}\text { Prospective } \\
\text { evaluation }\end{array}\end{array}$ & $\begin{array}{l}62 \text { pts evaluated. } \\
\text { Negative provoca- } \\
\text { tive discography: } \\
45 \text { pts. } \\
\text { Positive provocative } \\
\text { discography: } 17 \text { pts. }\end{array}$ & $\begin{array}{l}\text { Caudal epidural injec- } \\
\text { tions (1-3) with or } \\
\text { without steroids. }\end{array}$ & $\begin{array}{l}\text { Timing: } 1 \text { mos., } 3 \\
\text { mos., and } 6 \text { mos. } \\
\text { Outcome: average } \\
\text { pain, functional } \\
\text { status, psychologi- } \\
\text { cal status, narcotic } \\
\text { intake, and employ- } \\
\text { ment status. }\end{array}$ & $\begin{array}{l}69 \% \text { of the pts. in the nega- } \\
\text { tive discography group and } \\
65 \% \text { of the pts in the positive } \\
\text { discography group were in } \\
\text { successful category. }\end{array}$ & $\begin{array}{l}\text { Positive short- } \\
\text { term. Long-term } \\
\text { relief data not } \\
\text { available. }\end{array}$ \\
\hline
\end{tabular}




\section{Effectiveness}

Table 16 illustrates results of effectiveness of caudal epidural injections in managing discogenic pain without disc herniation or radiculitis.

\section{Cost Effectiveness}

The cost effectiveness of fluoroscopically directed caudal epidural steroids was $\$ 3,635$ and that of transforaminal steroids $\$ 2,927$ per year, whereas for interlaminar epidural steroids the cost was $\$ 6,024$ (107). In another study, the cost for one-year improvement for quality of life was $\$ 2,550$ in patients treated with caudal epidural with local anesthetic and/or steroids under fluoroscopy (66).

\section{Level of Evidence}

The level of evidence is variable for the 4 conditions evaluated. The evidence is based on randomized trials and observational studies.

The evidence is Level I for short- and long-term relief in managing chronic low back and lower extremity pain secondary to lumbar disc herniation and/or radiculitis. The evidence is Level II-1 or II-2 for caudal epidural injections in managing low back pain of postlumbar laminectomy syndrome and spinal stenosis. The evidence is Level I for short- and long-term relief in managing chronic low back pain of discogenic origin without disc herniation or radiculitis.

\section{Recommendations}

Based on the methodologic assessment and quality of evidence in grading recommendations by Guyatt et al (81) (Table 5), the recommendation for caudal epidural steroid injections in managing disc herniation and radiculitis and discogenic pain without disc herniation or radiculitis is $1 \mathrm{~A}$ or $1 \mathrm{~B} /$ strong recommendation with moderate to high quality evidence, with benefits outweighing risks and burdens, methodologic quality of supporting evidence derived from randomized controlled trials (RCTs).

Based on Guyatt et al's (81) recommendations, the recommendation for caudal epidural injections in managing patients with post-lumbar laminectomy syndrome and spinal stenosis is $1 \mathrm{~B}$ or $1 \mathrm{C}$. The evidence is obtained by RCTs without important limitations or observational studies. However, the evidence must be reconsidered if new evidence becomes available.

\section{Complications}

Even though rare, the most common and worrisome complications of caudal epidural injections are of 2 types: those related to the needle placement and those related to drug administration. Complications and side effects include infection, intravascular injection, extra epidural placement, hematoma formation, abscess formation, subdural injection, intracranial air

Table 16. Results of randomized and observational studies of effectiveness of caudal epidural steroid injections in managing discogenic pain.

\begin{tabular}{|c|c|c|c|c|c|c|c|c|}
\hline \multirow[b]{2}{*}{ Study } & \multirow[b]{2}{*}{$\begin{array}{c}\text { Study } \\
\text { Characteristics }\end{array}$} & \multirow[b]{2}{*}{$\begin{array}{l}\text { Methodological } \\
\text { Quality Scoring }\end{array}$} & \multirow[b]{2}{*}{ Participants } & \multicolumn{3}{|c|}{ Pain Relief } & \multicolumn{2}{|c|}{ Results } \\
\hline & & & & 3 mos. & 6 mos. & 12 mos. & $\begin{array}{c}\text { Short-term } \\
\text { relief } \leq 6 \\
\text { mos. }\end{array}$ & $\begin{array}{l}\text { Long- } \\
\text { term } \\
\text { relief }>6 \\
\text { mos. }\end{array}$ \\
\hline $\begin{array}{l}\text { Manchikanti et } \\
\text { al } 2008 \text { (68) }\end{array}$ & RA, DB & 72 & 64 & $78 \%$ & $\begin{array}{l}75 \% \text { to } \\
81 \%\end{array}$ & $72 \%$ & $\mathrm{P}$ & $\mathrm{P}$ \\
\hline $\begin{array}{l}\text { Manchikanti et } \\
\text { al } 2001 \text { (66) }\end{array}$ & $\mathrm{O}$ & 76 & 70 & $95 \%$ & $85 \%$ & $\begin{array}{c}61 \% \text { to } \\
73 \%\end{array}$ & $\mathrm{P}$ & $\mathrm{P}$ \\
\hline $\begin{array}{l}\text { Manchikanti et } \\
\text { al } 2002 \text { (65) }\end{array}$ & $\mathrm{O}$ & 73 & 62 & $86 \%$ & $60 \%$ & NA & $\mathrm{P}$ & NA \\
\hline
\end{tabular}

$\mathrm{RA}=$ randomized; $\mathrm{DB}$ = double blind $\mathrm{O}$ = observational; $\mathrm{P}=$ positive; $\mathrm{N}$ = negative; $\mathrm{NA}=$ not available 
injection, epidural lipomatosis, dural puncture, nerve damage, headache, increased intracranial pressure, vascular injury, cerebral vascular or pulmonary embolus, and effects of steroids.

Botwin et al (116) reported complications of fluoroscopically guided caudal epidural injections in 139 patients, who received 257 injections. Complications per injection included insomnia the night of the injection $(4.7 \%)$, transient non-positional headaches $(3.5 \%)$, increased back pain (3.1\%), facial flushing $(2.3 \%)$, vasovagal reactions $(0.8 \%)$, nausea $(0.8 \%)$, and increased leg pain $(0.4 \%)$. The incidence of minor complications was $15.6 \%$ per injection.

Manchikanti et al (117) reported complications with pain during the injection with back pain in $43 \%$ of the patients and leg pain in $22 \%$ of the patients. They also noted postoperative complications in $34 \%$ of the patients with soreness at the injection site in $18 \%$, increased pain in $5 \%$, muscle spasms in $4 \%$, swelling in $4 \%$, headache in $3 \%$, minor bleeding in $2 \%$, dizziness in $1 \%$, nausea and vomiting in $1 \%$, fever in $1 \%$, numbness in $1 \%$, and voiding difficulty in $1 \%$. Manchikanti et al $(117,118)$ reported with fluoroscopically guided caudal epidural injections intravascular placement in $14 \%$ of the patients. They also reported complications in $7 \%$ of the patients with soreness at the injection site in $6 \%$, increased pain in $1 \%$, muscle spasms in $1 \%$, headache in $1 \%$, and nausea and vomiting in $1 \%$.

Other much less common complications include transient blindness (119), retinal necrosis (120), serous chorioretinopathy $(121,122)$, retinal hemorrhage (123), persistent recurrent intractable hiccups (124), flushing (125), chemical meningitis (126), nerve damage (127), discitis (128-130), epidural hematoma (129), epidural abscess (130), and arachnoiditis (127).

The major theoretical complications of corticosteroid administration include suppression of pituitaryadrenal axis, hypercorticism, Cushing's syndrome, osteoporosis, avascular necrosis of bone, steroid myopathy, epidural lipomatosis, weight gain, fluid retention, and hyperglycemia $(44,45,68-71,131)$. The most commonly used steroids in neural blockade in the United States, methylprednisolone acetate, triamcinolone acetonide, betamethasone acetate, and phosphate mixture, have all been shown to be safe at epidural therapeutic doses in both clinical and experimental studies $(44,45,132-138)$.

Finally, radiation exposure is also a potential problem with damage to eyes, skin, and gonads (139-142).

\section{Discussion}

In this review, the effectiveness of caudal epidural injections was evaluated in patients with chronic low back and lower extremity pain secondary to disc herniation and radiculitis, post-lumbar laminectomy syndrome, lumbar spinal stenosis, and chronic low back pain of discogenic origin without radiculitis. This review showed Level I evidence for caudal epidural injections with or without steroids for patients with disc herniation or radiculitis and discogenic pain without disc herniation or radiculitis, whereas the indicated evidence was Level II-1 or II-2 for chronic low back and lower extremity pain secondary to post-lumbar laminectomy syndrome and spinal stenosis. The recommendation provided based on Guyatt et al's (81) criteria is $1 \mathrm{~A}$ or $1 \mathrm{~B} /$ strong for caudal epidural injections with or without steroids in patients secondary to lumbar disc herniation or radiculitis or patients with discogenic pain with or without disc herniation or radiculitis. The recommendation is $1 \mathrm{~B}$ or $1 \mathrm{C} /$ strong recommendation which may change when higher quality evidence becomes available for spinal stenosis and lumbar post surgery syndrome. In this review, 10 randomized trials and 5 observational studies were included in assessing the effectiveness in disc herniation, post lumbar laminectomy syndrome, spinal stenosis, and discogenic pain. A total of 6 randomized trials met criteria for inclusion evaluating the role of caudal epidural injections in managing pain of disc herniation or radiculitis, 3 randomized trials in managing low back pain of post-lumbar laminectomy syndrome, one randomized trial and 3 observational studies in managing pain secondary to lumbar spinal stenosis, and one randomized trial and 2 observational studies for managing chronic low back pain of discogenic origin without radiculitis and disc herniation.

The results of this systematic review are similar to some previous systematic reviews and guideline synthesis $(1,37,41)$, whereas they are in contradiction to other reviews $(36,38,43)$. However, while some previous reviews $(1,37,41)$ evaluated the evidence based on the route of administration, namely caudal, transforaminal, or lumbar interlaminar, others $(36,38,43)$ have evaluated combining multiple conditions and multiple techniques into one category, invariably leading to wrong conclusions (143-145). Further, in this study we have expanded the definition of shortterm relief to 6 months or less, whereas long-term 
relief is defined as longer than 6 months, providing robust evidence. Even then, the results were positive, for both short- and long-term for all the conditions referred. In addition, this is the first systematic review of the effectiveness of caudal epidural steroid injections as a separate category for post-lumbar laminectomy syndrome, spinal stenosis, and discogenic chronic low back pain.

The debate concerning caudal epidural steroid injections has been nurtured since the 1970s $(1,36-$ $38,41,43)$. The first systematic review of the effectiveness of caudal epidural steroid injections was performed by Kepes and Duncalf in 1985 (146). They concluded that the rationale for epidural and systematic steroids was not proven, however, in 1986, Benzon (147), utilizing the same studies, concluded that mechanical causes of low back pain, especially those accompanied by signs of nerve root irritation, may respond to epidural steroid injections. Thus, this illustrates that systematic reviews have provided different results based on the evaluators. More recently, ACOEM guidelines $(148,149)$ have provided negative evidence for caudal epidural injections along with other epidural injections. However, a reassessment (37) performed showed contrary results due to poor selection criteria and evidence synthesis by ACOEM guidelines. Manchikanti et al $(144,145)$ also showed the deleterious effects of poor quality assessment and the recommendations. The different results may be due to a multitude of factors including inappropriate evidence synthesis and conflicts of interest $(37,150-153)$. The debate concerning epidural steroid injections took center stage in the 1980s and 1990s with multiple publications $(133,147,154)$.

Bogduk et al (154) extensively studied caudal, interlaminar, and transforaminal epidural injections, including all the literature available at the time, and concluded that the balance of published evidence supports the therapeutic use of caudal epidurals. In 1995, Koes et al (43) reviewed 12 trials of lumbar and caudal epidural steroid injections and reported positive results from only 6 studies. However, review of their analysis showed that there were 5 studies for caudal epidural steroid injections and 7 studies for lumbar epidural steroid injections. However, 4 of the 5 studies involving caudal epidural steroid injections were positive, whereas 5 of 7 studies for lumbar interlaminar were negative. Their updated analysis (155) with the inclusion of 15 trials also arrived at the same conclusions with inappropriate allocation of the procedures. Multiple other investigators $(36,38,43)$ also have provided differing conclusions. In general, criticism against systematic reviews in the past has been directed toward methodology, small size of the study populations, and other limitations, including long-term follow-up and outcome parameters on the available literature. Further, paucity of literature has been a factor in the systematic evaluation of evidence for the effectiveness of epidural injections.

This systematic review provides information that caudal epidural injections are effective and there may not be any significant difference with the addition of steroids.

\section{Conclusion}

The results of this systematic review evaluating the effect of caudal epidural injections with or without steroids in managing various types of chronic low back and lower extremity pain emanating as a result of disc herniation or radiculitis, post lumbar laminectomy syndrome, spinal stenosis, and chronic discogenic pain without disc herniation or radiculitis has shown Level I evidence for short- and long-term relief of chronic pain secondary to disc herniation or radiculitis and discogenic pain without disc herniation or radiculitis. Further, this systematic review also provides indicated evidence of Level II-1 or II-2 for caudal epidural injections in managing chronic pain of post lumbar laminectomy syndrome and spinal stenosis. The results of this systematic review are provided utilizing contemporary systematic review methodology utilizing randomized trials and observational studies, even though most of the evidence was derived from randomized trials.

\section{Acknowledgments}

The authors wish to thank the editorial board of Pain Physician, for review and criticism in improving the manuscript; Vidyasagar Pampati, MSc, statistician; Sekar Edem for assistance in search of literature; and Tonie M. Hatton and Diane E. Neihoff, transcriptionists (Pain Management Center of Paducah), for their assistance in the preparation of this manuscript. 


\section{References}

1. Boswell MV, Trescot AM, Datta S, Schultz DM, Hansen HC, Abdi S, Sehgal N, Shah RV, Singh V, Benyamin RM, Patel VB, Buenaventura RM, Colson JD, Cordner HJ, Epter RS, Jasper JF, Dunbar EE, Atluri SL, Bowman RC, Deer TR, Swicegood JR, Staats PS, Smith HS, Burton AW, Kloth DS, Giordano J, Manchikanti L. Interventional techniques: Evidencebased practice guidelines in the management of chronic spinal pain. Pain Physician 2007; 10:7-111.

2. Verhaak PF, Kerssens JJ, Dekker J, Sorbi MJ, Bensing JM. Prevalence of chronic benign pain disorder among adults: A review of the literature. Pain 1998; 77:231-239.

3. Gureje O, Von Korff M, Simon GE, Gater R. Persistent pain and well-being: $A$ World Health Organization Study in Primary Care. JAMA 1998; 280:147-151.

4. Elliott AM, Smith BH, Hannaford PC, Smith WC, Chambers WA. The course of chronic pain in the community: Results of a 4-year follow-up study. Pain 2002; 99:299-307.

5. Yeung SS, Genaidy A, Deddens J, Alhe$\operatorname{mood} A$, Leung PC. Prevalence of musculoskeletal symptoms in single and multiple body regions and effects of perceived risk of injury among manual handling workers. Spine 2002; 27:21662172.

6. Cassidy JD, Carroll LJ, Cotê P. The Saskatchewan Health and Back Pain Survey. The prevalence of low back pain and related disability in Saskatchewan Adults. Spine 1998; 23:1860-1867.

7. Walker BF, Muller R, Grant WD. Low back pain in Australian adults: Prevalence and associated disability. J Manipulative Physiol Ther 2004; 27:238-244.

8. Bressler HB, Keyes WJ, Rochon PA, Badley $\mathrm{E}$. The prevalence of low back pain in the elderly. A systematic review of the literature. Spine 1999; 24:1813-1819.

9. Cecchi F, Debolini P, Lova RM, Macchi C, Bandinelli S, Bartali B, Lauretani F, Benvenuti E, Hicks G, Ferrucci L. Epidemiology of back pain in a representative cohort of Italian persons 65 years of age and older: The InCHIANTI study. Spine 2006; 31:1149-1155.

10. Edmond SL, Felson DT. Function and back symptoms in older adults. I Am Geriatr Soc 2003; 51:1702-1709.

11. Luo X, Pietrobon R, Sun SX, Liu GG, Hey L. Estimates and patterns of di- rect health care expenditures among individuals with back pain in the United States. Spine 2004; 29:79-86.

12. Walker BF, Muller R, Grant WD. Low back pain in Australian adults: The economic burden. Asia Pac J Public Health 2003; 15:79-87.

13. Kuslich SD, Ulstrom CL, Michael C). The tissue origin of low back pain and sciatica: A report of pain response to tissue stimulation during operation on the lumbar spine using local anesthesia. Orthop Clin North Am 1991; 22:181-187.

14. Konstantinou K, Dunn KM. Sciatica: Review of epidemiological studies and prevalence estimates. Spine 2008; 33:2464-2472.

15. Mixter WJ, Barr JS. Rupture of the intervertebral disc with involvement of the spinal canal. N Eng J Med 1934; 211:210215.

16. Mixter WJ, Ayers JB. Herniation or rupture of the intervertebral disc into the spinal canal. N Engl J Med 1935; 213:385-395.

17. Manchikanti L, Singh V, Pampati V, Damron KS, Barnhill RC, Beyer CD, Cash KA. Evaluation of the relative contributions of various structures in chronic low back pain. Pain Physician 2001; 4:308-316.

18. Wheeler AH, Murrey DB. Chronic lumbar spine and radicular pain: Pathophysiology and treatment. Curr Pain Headache Rep 2002; 6:97-105.

19. Hadjipavlou AG, Tzermiadianos MN, Bogduk N, Zindrick MR. The pathophysiology of disc degeneration: A critical review. J Bone Joint Surg Br 2008; 90:1261-1270.

20. Norimoto M, Ohtori S, Yamashita M, Inoue G, Yamauchi K, Koshi T, Suzuki M, Orita S, Eguchi Y, Sugiura A, Ochiai N, Takaso M, Takahashi K. Direct application of the TNF-alpha inhibitor, etanercept, does not affect CGRP expression and phenotypic change of DRG neurons following application of nucleus pulposus onto injured sciatic nerves in rats. Spine 2008; 33:2403-2408.

21. Genevay S, Finckh A, Payer M, Mezin F, Tessitore E, Gabay C, Guerne PA. Elevated levels of tumor necrosis factor-alpha in periradicular fat tissue in patients with radiculopathy from herniated disc. Spine 2008; 33:2041-2046.

22. Sugiura A, Ohtori S, Yamashita M, Inoue G, Yamauchi K, Koshi T, Suzuki M, Norimoto M, Orita S, Eguchi Y, Taka- hashi Y, Watanabe TS, Ochiai N, Takaso M, Takahashi K. Existence of nerve growth factor receptors, tyrosine kinase $a$ and p75 neurotrophin receptors in intervertebral discs and on dorsal root ganglion neurons innervating intervertebral discs in rats. Spine 2008; 33:2047-2051.

23. Yamashita M, Ohtori S, Koshi T, Inoue G, Yamauchi K, Suzuki M, Takahashi $\mathrm{K}$. Tumor necrosis factor-alpha in the nucleus pulposus mediates radicular pain, but not increase of inflammatory peptide, associated with nerve damage in mice. Spine 2008; 33:1836-1842.

24. Cummins J, Lurie JD, Tosteson TD, Hanscom B, Abdu WA, Birkmeyer NJ, Herkowitz $\mathrm{H}$, Weinstein J. Descriptive epidemiology and prior healthcare utilization of patients in the Spine Patient Outcomes Research Trial's (SPORT) three observational cohorts: Disc herniation, spinal stenosis, and degenerative spondylolisthesis. Spine 2006; 31:806-814.

25. Weinstein JN, Tosteson TD, Lurie JD, Tosteson AN, Blood E, Hanscom B, Herkowitz H, Cammisa F, Albert T, Boden SD, Hilibrand A, Goldberg H, Berven S, An H; SPORT Investigators. Surgical versus nonsurgical therapy for lumbar spinal stenosis. $N$ Engl J Med 2008; 358:794-810.

26. ECRI Health Technology Assessment Group. Treatment of degenerative lumbar spinal stenosis. Evid Rep Technol Assess (Summ) 2001; 32:1-5.

27. Schofferman J, Reynolds J, Herzog R, Covington E, Dreyfuss P, O'Neill C. Failed back surgery: Etiology and diagnostic evaluation. Spine J 2003; 3:400403.

28. Waguespack A, Schofferman J, Slosar P, Reynolds J. Etiology of long-term failures of lumbar spine surgery. Pain Med 2002; 3:18-22.

29. Waddell G, Kummel EG, Lotto WN, Graham JD, Hall H, McCulloch JA. Failed lumbar disc surgery and repeat surgery following industrial injury. I Bone Joint Surg Am 1979; 61:201-207.

30. Ross JS, Robertson JT, Frederickson RC, Petrie JL, Obuchowski N, Modic MT, de Tribolet N. Association between peridural scar and recurrent radicular pain after lumbar discectomy: Magnetic resonance evaluation. Neurosurgery 1996; 38:855-863. 
31. Fritsch EW, Heisel J, Rupp S. The failed back surgery syndrome. Reasons, intraoperative findings, and long-term results: A report of 182 operative treatments. Spine 1996; 21:626-633.

32. Manchikanti L. Medicare in interventional pain management: A critical analysis. Pain Physician 2006; 9:171198.

33. Manchikanti L, Giordano J. Physician payment 2008 for interventionalists: Current state of health care policy. Pain Physician 2007; 10:607-626.

34. Manchikanti L, Boswell MV. Interventional techniques in ambulatory surgical centers: A look at the new payment system. Pain Physician 2007; 10:627650.

35. Specialty Utilization data files from Centers for Medicare and Medicaid Services. Medicare. www.cms.hhs.gov/

36. Staal JB, de Bie R, de Vet HC, Hildebrandt J, Nelemans P. Injection therapy for subacute and chronic low-back pain. Cochrane Database Syst Rev 2008; 3:CDo01824.

37. Manchikanti L, Singh V, Derby R, Schultz DM, Benyamin RM, Prager JP, Hirsch JA. Reassessment of evidence synthesis of occupational medicine practice guidelines for interventional pain management. Pain Physician 2008; 11:393482.

38. Armon C, Argoff CE, Samuels J, Backonja MM; Therapeutics and Technology Assessment Subcommittee of the American Academy of Neurology. Assessment: Use of epidural steroid injections to treat radicular lumbosacral pain: Report of the Therapeutics and Technology Assessment Subcommittee of the American Academy of Neurology. Neurology 2007; 68:723-729.

39. Friedly J, Chan L, Deyo R. Increases in lumbosacral injections in the Medicare population: 1994 to 2001. Spine 2007; 32:1754-1760.

40. Friedly J, Nishio I, Bishop MJ, Maynard C. The relationship between repeated epidural steroid injections and subsequent opioid use and lumbar surgery. Arch Phys Med Rehabil 2008; 89:10111015.

41. Abdi S, Datta S, Trescot AM, Schultz DM, Adlaka R, Atluri SL, Smith HS, Manchikanti L. Epidural steroids in the management of chronic spinal pain: A systematic review. Pain Physician 2007; 10:185-212.

42. Airaksinen O, Brox JI, Cedraschi C, Hil- debrandt J, Klaber-Moffett J, Kovacs F, Mannion AF, Reis S, Staal JB, Ursin $\mathrm{H}$, Zanoli G. Chapter 4: European guidelines for the management of chronic nonspecific low back pain. Eur Spine J 2006; 15:S192-S300.

43. Koes BW, Scholten RJ, Mens JM, Bouter LM. Efficacy of epidural steroid injections for low back pain and sciatica: A systematic review of randomized clinical trials. Pain 1995; 63:279-288.

44. Manchikanti L. Role of neuraxial steroids in interventional pain management. Pain Physician 2002; 5:182-199.

45. Manchikanti L. Pharmacology of neuraxial steroids. In: Manchikanti L, Singh $\mathrm{V}$ (eds). Interventional Techniques in Chronic Spinal Pain. ASIPP Publishing, Paducah, KY, 2007, pp 167-184.

46. Byrod G, Otani K, Brisby H, Rydevik B, Olmarker K. Methylprednisolone reduces the early vascular permeability increase in spinal nerve roots induced by epidural nucleus pulposus application. J Orthop Res 2000; 18:983-987.

47. Flower RJ, Blackwell GJ. Anti-inflammatory steroid induced biosynthesis of a phospholipase A2 inhibitor which prevents prostaglandin generation. Nature 1979; 278:456-459.

48. Lundin A, Magnuson A, Axelsson K, Nilsson O, Samuelsson L. Corticosteroids preoperatively diminishes damage to the C-fibers in microscopic lumbar disc surgery. Spine 2005; 30:23622367.

49. Hua SY, Chen YZ. Membrane receptormediated electrophysiological effects of glucocorticoid on mammalian neurons. Endocrinology 1989; 124:687691.

50. Hayashi N, Weinstein JN, Meller ST, Lee HM, Spratt KF, Gebhart GF. The effect of epidural injection of betamethasone or bupivacaine in a rat model of lumbar radiculopathy. Spine 1998; 23:877885.

51. Lee HM, Weinstein JN, Meller ST, Hayashi N, Spratt KF, Gebhart GF. The role of steroids and their effects on phospholipase A2: An animal model of radiculopathy. Spine 1998; 23:11911196.

52. Minamide A, Tamaki T, Hashizume $\mathrm{H}$, Yoshida M, Kawakami M, Hayashi N. Effects of steroids and lipopolysaccharide on spontaneous resorption of herniated intervertebral discs: An experimental study in the rabbit. Spine 1998; 23:870-876.
53. Kingery WS, Castellote JM, Maze M. Methylprednisolone prevents the development of autotomy and neuropathic edema in rats, but has no effect on nociceptive thresholds. Pain 1999; 80:555-566.

54. Kawakami M, Weinstein JN, Chatani K, Spratt KF, Meller ST, Gebhart GF. Experimental lumbar radiculopathy. Behavioral and histologic changes in a model of radicular pain after spinal nerve root irritation with chromic gut ligatures in the rat. Spine 1994; 19:1795-1802.

55. Pasqualucci A, Varrassi G, Braschi A, Peduto VA, Brunelli A, Marinangeli F, Gori F, Colò F, Paladín A, Mojoli F. Epidural local anesthetic plus corticosteroid for the treatment of cervical brachial radicular pain: Single injection verus continuous infusion. Clin J Pain 2007; 23:551-557.

56. Mao J, Chen LL. Systemic lidocaine for neuropathic pain relief. Pain 2000; 87:7-17.

57. Pasqualucci A. Experimental and clinical studies about the preemptive analgesia with local anesthetics. Possible reasons of the failure. Minerva Anestesiol 1998; 64:445-457.

58. Lavoie PA, Khazen T, Filion PR. Mechanisms of the inhibition of fast axonal transport by local anesthetics. Neuropharmacology 1989; 28:175-181.

59. Bisby MA. Inhibition of axonal transport in nerves chronically treated with local anesthetics. Exp Neurol 1975; 47:481-489.

6o. Melzack R, Coderre TJ, Katz J, Vaccarino AL. Central neuroplasticity and pathological pain. Ann N Y Acad Sci 2001; 933:157-174.

61. Cassuto J, Sinclair R, Bonderovic M. Anti-inflammatory properties of local anesthetics and their present and potential clinical implications. Acta Anaesthesiol Scand 2006; 50:265-282.

62. Riew KD, Park JB, Cho YS, Gilula L, Patel A, Lente LG, Bridwell KH. Nerve root blocks in the treatment of lumbar radicular pain. A minimum five-year follow-up. J Bone Joint Surg Am 2006; 88:1722-1725.

63. Bonica JJ. Current role of nerve blocks in diagnosis and therapy of pain. In: Bonica JJ (ed). Advances in Neurology, Vol. 4. Raven Press, New York, 1974, pp 445-453.

64. Manchikanti L. Interventional pain management: Past, present, and future. The Prithvi Raj lecture: Present- 
ed at the 4 th World Congress-World Institute of Pain, Budapest, 2007. Pain Pract 2007; 7:357-371.

65. Manchikanti L, Singh V, Rivera JJ, Pampati V, Beyer CD, Damron KS, Barnhill RC. Effectiveness of caudal epidural injections in discogram positive and negative chronic low back pain. Pain Physician 2002; 5:18-29.

66. Manchikanti L, Pampati V, Rivera JJ, Beyer CD, Damron KS, Barnhill RC. Caudal epidural injections with sarapin steroids in chronic low back pain. Pain Physician 2001; 4:322-335.

67. Sato C, Sakai A, Ikeda Y, Suzuki H, Sakamoto $A$. The prolonged analgesic effect of epidural ropivacaine in a rat model of neuropathic pain. Anesth Analg 2008; 106:313-320.

68. Manchikanti L, Cash KA, McManus CD, Pampati V, Smith HS. Preliminary results of randomized, equivalence trial of fluoroscopic caudal epidural injections in managing chronic low back pain: Part 1. Discogenic pain without disc herniation or radiculitis. Pain Physician 2008; 11:785-800.

69. Manchikanti L, Singh V, Cash KA, Pampati V, Damron KS, Boswell MV. Preliminary results of randomized, equivalence trial of fluoroscopic caudal epidural injections in managing chronic low back pain: Part 2. Disc herniation and radiculitis. Pain Physician 2008; 11:801-815.

70. Manchikanti L, Singh V, Cash KA, Pampati V, Datta S. Preliminary results of randomized, equivalence trial of fluoroscopic caudal epidural injections in managing chronic low back pain: Part 3. Post surgery syndrome. Pain Physician 2008; 11:817-831.

71. Manchikanti L, Cash KA, McManus CD, Pampati V, Abdi S. Preliminary results of randomized, equivalence trial of fluoroscopic caudal epidural injections in managing chronic low back pain: Part 4. Spinal stenosis. Pain Physician 2008; 11:833-848.

72. Tachihara H, Sekiguchi M, Kikuchi S, Konno S. Do corticosteroids produce additional benefit in nerve root infiltration for lumbar disc herniation. Spine 2008; 33:743-747.

73. West S, King V, Carey TS, Lohr KN, McKoy N, Sutton SF, Lux L. Systems to Rate the Strength of Scientific Evidence, Evidence Report, Technology Assessment No. 47. AHRQ Publication No. 02E016. Rockville, MD: Agency for Healthcare Research and Quality, 2002. www. thecre.com/pdf/ahrq-system-strength. pdf

74. Atluri S, Datta S, Falco FJ, Lee M. Systematic review of diagnostic utility and therapeutic effectiveness of thoracic facet joint interventions. Pain Physician 2008; 11:611-629.

75. Benyamin R, Singh V, Parr AT, Conn A, Diwan S, Abdi S. Systematic review of the effectiveness of cervical epidurals in the management of chronic neck pain. Pain Physician 2009; 12:137-157.

76. Parr AT, Diwan S, Abdi S. Lumbar interlaminar epidural injections in managing chronic low back and lower extremity pain: A systematic review. Pain Physician 2009; 12:163-188.

77. Buenaventura R, Datta S, Abdi S. Smith $\mathrm{H}$. Systematic review of lumbar transforaminal epidural steroid injections. Pain Physician 2009; 12:233-251.

78. Helm S, Hayek S, Benyamin R, Manchikanti L. Systematic review of the effectiveness of thermal annular procedures in treating discogenic low back pain. Pain Physician 2008; 12:211236.

79. van Tulder $M$, Furlan $A$, Bombardier C, Bouter L, Editorial Board of the Cochrane Collaboration Back Review Group. Updated method guidelines for systematic reviews in the Cochrane Collaboration Back Review Group. Spine 2003; 28:1290-1299.

80. Berg AO, Allan JD. Introducing the third U.S. Preventive Services Task Force. Am J Prev Med 2001; 20:21-35.

81. Guyatt $\mathrm{G}$, Gutterman D, Baumann MH, Addrizzo-Harris D, Hylek EM, Phillips B, Raskob G, Lewis SZ, Schünemann $\mathrm{H}$. Grading strength of recommendations and quality of evidence in clinical guidelines. Report from an American College of Chest Physicians Task Force. Chest 2006; 129:174-181.

82. Dashfield A, Taylor M, Cleaver J, Farrow D. Comparison of caudal steroid epidural with targeted steroid placement during spinal endoscopy for chronic sciatica: A prospective, randomized, double-blind trial. $\mathrm{Br} /$ Anaesthesia 2005; 94:514-519.

83. Mathews JA, Mills SB, Jenkins VM, Grimes SM, Morkel MJ, Mathews W, Scott CM, Sittampalam Y. Back pain and sciatica: Controlled trials of manipulation, traction, sclerosant and epidural injections. Br J Rheumatol 1987; 26:416-423.

84. Breivik H, Hesla PE, Molnar I, Lind B.
Treatment of chronic low back pain and sciatica. Comparison of caudal epidural injections of bupivacaine and methylprednisolone with bupivacaine followed by saline. In: Bonica JJ, Albe-Fesard D (eds). Advances in Pain Research and Therapy. Raven Press, New York, 1976, pp 927-932.

85. Bush K, Hillier S. A controlled study of caudal epidural injections of triamcinolone plus procaine for the management of intractable sciatica. Spine 1991; 16:572-575.

86. Revel M, Auleley GR, Alaoui S, Nguyen M, Duruoz T, Eck-Michaud S, Roux C, Amor B. Forceful epidural injections for the treatment of lumbosciatic pain with post-operative lumbar spinal fibrosis. Rev Rhum Engl Ed 1996; 63:270-277.

87. Meadeb J, Rozenberg S, Duquesnoy B, Kuntz JL, Le Loet X, Sebert JL, Le Goff P, Fallut M, Marty M, Blevin S, Guggenbuhl P, Chales G, Duvauferrier R. Forceful sacrococcygeal injections in the treatment of postdiscectomy sciatica. A controlled study versus glucocorticoid injections. Joint Bone Spine 2001; 68:43-49.

88. McGregor AH, Anjarwalla NK, Stambach T. Does the method of injection alter the outcome of epidural injections? J Spinal Disord 2001; 14:507-510.

89. Hesla PE, Breivik H. Epidural analgesia and epidural steroid injection for treatment of chronic low back pain and sciatica. Tidsskr Nor Laegeforen 1979; 99:936-939.

90. Czarski Z. Leczenie rwy kulszowej wstrzykiwaniem hydrokortyzonu inowokainy do rozworu kryzowego. Przeglad Kekarski 1965; 21:511-513.

91. Beliveau P. A comparison between epidural anesthesia with and without corticosteroids in the treatment of sciatica. Rheum Phys Med 1971; 11:40-43.

92. Anwar A, Zaidah I, Rozita R. Prospective randomized single blind study of epidural steroid injection comparing triamcinolone acetonide with methylprednisolone acetate. APLAR / Rheumatology 2005; 8:1-53.

93. Ackerman WE 3rd, Ahmad M. The efficacy of lumbar epidural steroid injections in patients with lumbar disc herniations. Anesth Analg 2007; 104:12171222.

94. Dincer U, Kiralp MZ, Cakar E, Yasar E, Dursan H. Caudal epidural injection versus non-steroidal anti-inflammatory drugs in the treatment of low back pain accompanied with radicular pain. Joint 
Bone Spine 2007; 74:467-471.

95. Bronfort G, Evans RL, Maiers M, Anderson AV. Spinal manipulation, epidural injections, and self-care for sciatica: A pilot study for a randomized clinical trial. J Manipulative Physiol Ther 2004; 27:503-508.

96. Ciocon JO, Galindo-Ciocon D, Amaranath L, Galindo D. Caudal epidural blocks for elderly patients with lumbar canal stenosis. J Am Geriatr Soc 1994; 42:593-596.

97. Galindo-Ciocon D. Use of caudal epidural blocks to relieve lumbar canal stenotic pain in elderly patients. AORN J 1996; 63:254-257.

98. Yates DW. A comparison of the types of epidural injection commonly used in the treatment of low back pain and sciatica. Rheum Rehab 1978; 17:181-186.

99. Mohamed MM, Ahmed M, Chaudary M. Caudal epidural injection for L4-5 versus L5-S1 disc prolapse: Is there any difference in the outcome? I Spinal Disord Tech 2007; 20:49-52.

100. Barré L, Lutz GE, Southern D, Cooper G. Fluoroscopically guided caudal epidural steroid injections for lumbar spinal stenosis: A retrospective evaluation of long-term efficacy. Pain Physician 2004; 7:187-193.

101. Kim SI, Sadove MS. Caudal-epidural corticosteroids in post-laminectomy syndrome: Treatment for low-back pain. Compr Ther 1975; 1:57-60.

102. Lindholm R, Salenius P. Caudal, epidural administration of anaesthetics and corticoids in the treatment of low back pain. Acta Orthop Scand 1964; 34:114116.

103. Waldman SD. The caudal epidural administration of steroids in combination with local anesthetics in the palliation of pain secondary to radiographically documented lumbar herniated disc: A prospective outcome study with 6 months follow-up. Pain Clinic 1998; 11:43-49.

104. Delport EG, Cucuzzella AR, Marley JK, Pruitt CM, Fisher JR. Treatment of lumbar spinal stenosis with epidural steroid injections: A retrospective outcome study. Arch Phys Med Rehabil 2004; 85:479-484.

105. Price CM, Rogers PD, Prosser AS, Arden NK. Comparison of the caudal and lumbar approaches to the epidural space. Ann Rheum Dis 2000; 59:879-882.
106. Banaszkiewicz PA, Kader D, Wardlaw D. The role of caudal epidural injections in the management of low back pain. Bull Hosp Jt Dis 2003; 61:127-131.

107. Manchikanti L, Pakanati RR, Pampati V. Comparison of three routes of epidural steroid injections in low back pain. Pain Digest 1999; 9:277-285.

108. Hauswirth R, Michot F. Caudal epidural injection in the treatment of low back pain. Ischweizerische Medizinische Wochenschrift 1982; 112:222-225.

109. Goebert HW Jr, Jallo SJ, Gardner WJ, Wasmuth CE. Painful radiculopathy treated with epidural injections of procaine and hydrocortisone acetate: Results in 113 patients. Anesth Analg 1961; 140:130-134.

110. Southern D, Lutz GE, Cooper G, Barré L. Are fluoroscopic caudal epidural steroid injections effective for managing chronic low back pain? Pain Physician 2003; 6:167-172.

111. Hoogmartens M, Morelle P. Epidural injection in the treatment of spinal stenosis. Acta Orthop Belg 1987; 53:409411.

112. Botwin K, Brown LA, Fishman M, Rao $\mathrm{S}$. Fluoroscopically guided caudal epidural steroid injections in degenerative lumbar spine stenosis. Pain Physician 2007; 10:547-558.

113. Khan MU, Hussain SZ. Role of psoas compartment and caudal epidural steroid injection in spinal stenosis patients associated with low back pain and lower limb radiculopathy. J Pak Med Assoc 2008; 58:490-493.

114. Sheehan J, Shaffrey C, Jane J. Degenerative lumbar stenosis: The neurosurgical perspective. Clin Orthop 2001; 384:61-74.

115. Simotas AC, Dorey FJ, Hansraj KK, Cammisa F Jr. Non-operative treatment for lumbar spinal stenosis: Clinical outcome results and a 3-year survivorship analysis. Spine 2000; 25:197-204.

116. Botwin KP, Gruber RD, Bouchlas CG, Torres-Ramos FM, Hanna A, Rittenberg J, Thomas SA. Complications of fluoroscopically guided caudal epidural injections. Arch Phys Med Rehabil 2001; 80:416-424.

117. Manchikanti L, Cash KA, Pampati V, McManus CD, Damron KS. Evaluation of fluoroscopically guided caudal epidural injections. Pain Physician 2004; 7:81-92.

118. Manchikanti L, Bakhit CE, Pampati V.
The role of epidurography in caudal neuroplasty. Pain Digest 1998; 8:277281.

119. Young WF. Transient blindness after lumbar epidural steroid injection: A case report and literature review. Spine 2002; 27:E476-E477.

120. Browning DJ. Acute retinal necrosis following epidural steroid injections. Am J Ophthalmol 2003; 136:192-194.

121. lida T, Spaide RF, Negrao SG, Carvalho CA, Yannuzzi LA. Central serous chorioretinopathy after epidural corticosteroid injection. Am J Ophthalmol 2001; 132:423-425.

122. Pizzimenti JJ, Daniel KP. Central serous chorioretinopathy after epidural steroids. Pharmacotherapy 2005; 25:11411146.

123. Kusher FH, Olson JC. Retinal hemorrhage as a consequence of epidural steroid injection. Arch Opthalmol 1995; 113:309-313.

124. McAllister RK, McDavid AJ, Meyer TA, Bittenbinder TM. Recurrent persistent hiccups after epidural steroid injection and analgesia with bupivacaine. Anesth Analg 2005; 100:1834-1836.

125. Everett CR, Baskin MN, Novoseletsky $D$, Speach D, Patel R. Flushing as a side effect following lumbar transforaminal epidural steroid injection. Pain Physician 2004; 7:427-429.

126. Gutknecht DR. Chemical meningitis following epidural injections of corticosteroids (Letter). Am J Med 1987; 82:570.

127. Nelson DA, Landau WM. Intraspinal steroids: History, efficacy, accidentality, and controversy with review of United States Food and Drug Administration reports. I Neurol Neurosurg Psychiatry 2001; 70:433-443.

128. Yue WM, Tan SB. Distant skip level discitis and vertebral osteomyelitis after caudal epidural injection: A case report of a rare complication of epidural injections. Spine 2003; 28:E209-E211.

129. Markham JW, Lynge HN, Stahlman GE. The syndrome of spontaneous spinal epidural hematoma. Report of three cases. J Neurosurg 1967; 26:334-341.

130. Hooten WM, Kinney MO, Huntoon MA. Epidural abscess and meningitis after epidural corticosteroid injection. Mayo Clin Proc 2004; 79:682-686.

131. Brill S, Swartz A, Brill G. Epidural steroid injections do not induce weight gain. Curr Drug Saf 2007; 2:113-116.

132. Delaney TJ, Rowlingson JC, Carron H, 
Butler A. Epidural steroid effects on nerves and meninges. Anesth Analg 1980; 58:610-614.

133. Abram SE, Marsala M, Yaksh TL. Analgesic and neurotoxic effects of intrathecal corticosteroids in rats. Anesthesiology 1994; 81:1198-1205.

134. Chino N, Awad EA, Kottke FJ. Pathology of propylene glycol administered by perineural and intramuscular injection in rats. Arch Phys Med Rehab 1974; 55:33-38.

135. Latham JM, Fraser RD, Moore RJ, Blumbergs PC, Bogduk N. The pathologic effects of intrathecal betamethasone. Spine 1997; 22:1558-1562.

136. Robustelli della Cuna FS, Mella M, Magistrali G, Ricci M, Losurdo A, Goglio AM. Stability and compatibility of methylprednisolone acetate and ropivacaine hydrochloride in polypropylene syringes for epidural administration. Am J Health Syst Pharm 2001; 58:1753-1756.

137. Manchikanti L, Pampati V, Beyer CD, Damron KS, Cash KA, Moss TL. The effect of neuraxial steroids on weight and bone mass density: A prospective evaluation. Pain Physician 2000; 3:357366.

138. Davidson EM, Sklar EM, Ginosar Y, Abdi S, Bhatia RG, Garcia L, Hulen RB, Arheart KL, Birnbach DJ. Evaluation of magnetic resonance imaging following neuraxial steroid administration: Does epidural injection produce pathologic findings. Reg Anesth Pain Med 2008; 33:326-331.

139. Manchikanti L, Cash KA, Moss TL, Pampati V. Effectiveness of protective measures in reducing risk of radiation exposure in interventional pain management: A prospective evaluation. Pain Physician 2003; 6:301-305.

140. Manchikanti L, Cash KA, Moss TL, Rivera JJ, Pampati V. Risk of whole body radiation exposure and protective measures in fluoroscopically guided interventional techniques: A prospective evaluation. BMC Anesthesiol 2003;
3:2.

141. Manchikanti L, Cash KA, Moss TL, Pampati V. Radiation exposure to the physician in interventional pain management. Pain Physician 2002; 5:385-393.

142. Botwin KP, Freeman ED, Gruber RD, Torres-Ramos FM, Bouchlas C, Sanelli JT, Hanna AF. Radiation exposure to a physician performing fluoroscopically guided caudal epidural steroid injections. Pain Physician 2001; 4:343-348.

143. Manchikanti L, Boswell MV, Giordano J, Kaplan E. Assessment: Use of epidural steroid injections to treat radicular lumbosacral pain: Report of the Therapeutics and Technology Assessment Subcommittee of the American Academy of Neurology. Neurology 2007; 69:1190.

144. Manchikanti L, Singh V, Derby R, Helm S, Trescot AM, Staats PS, Prager JP, Hirsch JA. Review of occupational medicine practice guidelines for interventional pain management and potential implications. Pain Physician 2008; 11:271-289.

145. Manchikanti L, Singh V, Helm S, Trescot AM, Hirsch JA. A critical appraisal of 2007 American College of Occupational and Environmental Medicine (ACOEM) practice guidelines for interventional pain management: An independent review utilizing AGREE, AMA, IOM, and other criteria. Pain Physician 2008; 11:291-310.

146. Kepes ER, Duncalf D. Treatment of backache with spinal injections of local anesthetics, spinal and systemic steroids. Pain 1985; 22:33-47.

147. Benzon HT. Epidural steroid injections for low back pain and lumbosacral radiculopathy. Pain 1986; 24:277-295.

148. American College of Occupational and Environmental Medicine Low Back Disorders Chapter. In Occupational Medicine Practice Guidelines: Evaluation and Management of Common Health Problems and Functional Recovery of Workers, Second Edition. American College of Occupational and Environ- mental Medicine, Elk Grove Village, 2007.

149. American College of Occupational and Environmental Medicine. Chronic Pain Chapter (revised 2008). In: Occupational Medicine Practice Guidelines: Evaluation and Management of Common Health Problems and Functional Recovery of Workers, Second Edition. American College of Occupational and Environmental Medicine, Elk Grove Village, Epublished August 14, 2008.

150. Manchikanti L. Evidence-based medicine, systematic reviews, and guidelines in interventional pain management: Part 1: Introduction and general considerations. Pain Physician 2008; 11:161-186.

151. Manchikanti L, Hirsch JA, Smith HS. Evidence-based medicine, systematic reviews, and guidelines in interventional pain management: Part 2: Randomized controlled trials. Pain Physician 2008; 11:717-775.

152. Manchikanti L, Smith HS, Hirsch JA. Evidence-based medicine, systematic reviews, and guidelines in interventional pain management: Part 3: Observational studies. Pain Physician 2009; 12:35-72.

153. Manchikanti L, Smith HS, Hirsch JA. Evidence-based medicine, systematic reviews, and guidelines in interventional pain management: Part 4: Observational studies. Pain Physician 2009;12:73108.

154. Bogduk N, Brazenor G, Christophidis N, Cherry D, Fraser R, Jenkins J, Little TF, Ditton J, Jeffries R. Epidural Use of Steroids in the Management of Back Pain. Report of Working Party on Epidural Use of Steroids in the Management of Back Pain. National Health and Medical Research Council: Canberra, Commonwealth of Australia; 1994, pp 1-76.

155. Koes BW, Scholten RJ, Mens JMA, Bouter LM. Epidural steroid injections for low back pain and sciatica. An updated systematic review of randomized clinical trials. Pain Digest 1999; 9:241-247. 
